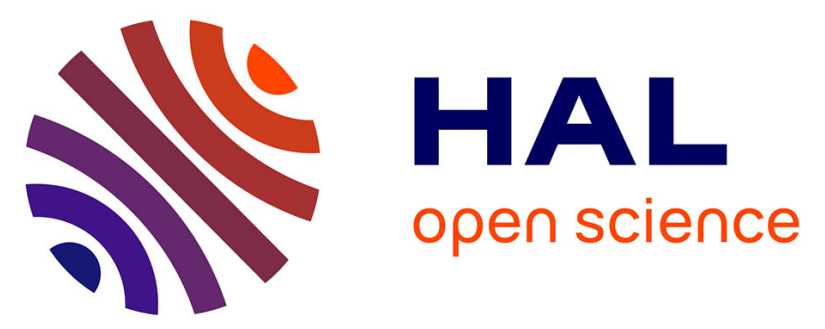

\title{
Paleoclimate variations and impact on groundwater recharge in multi-layer aquifer systems using a multi-tracer approach (northern Aquitaine basin, France)
}

Marc Saltel, Romain Rebeix, Bertrand Thomas, Michel Franceschi, Bernard Lavielle, Pascal Bertran

\section{To cite this version:}

Marc Saltel, Romain Rebeix, Bertrand Thomas, Michel Franceschi, Bernard Lavielle, et al.. Paleoclimate variations and impact on groundwater recharge in multi-layer aquifer systems using a multitracer approach (northern Aquitaine basin, France). Hydrogeology Journal, 2019, 27, pp.1439-1457. 10.1007/s10040-019-01944-x . hal-02154742

\section{HAL Id: hal-02154742 \\ https://hal.science/hal-02154742}

Submitted on 21 Aug 2020

HAL is a multi-disciplinary open access archive for the deposit and dissemination of scientific research documents, whether they are published or not. The documents may come from teaching and research institutions in France or abroad, or from public or private research centers.
L'archive ouverte pluridisciplinaire HAL, est destinée au dépôt et à la diffusion de documents scientifiques de niveau recherche, publiés ou non, émanant des établissements d'enseignement et de recherche français ou étrangers, des laboratoires publics ou privés. 


\title{
Paleoclimate variations and impact on groundwater recharge in multi-layer aquifer systems using a multi-tracer approach (northern Aquitaine basin, France)
}

\author{
Marc Saltel $^{1} \cdot$ Romain Rebeix $^{2,3} \cdot$ Bertrand Thomas $^{2,3} \cdot$ Michel Franceschi $^{4,5} \cdot$ Bernard Lavielle $^{2,3} \cdot$ Pascal Bertran $^{6,7}$
}

\begin{abstract}
The northern Aquitaine basin (southwest France) is a large multi-layer aquifer system that contains groundwater with strong residence-time variability ranging from years to tens of thousands of years. This system constitutes an archive of paleoclimate variations. A multi-parameter approach involving isotopic tracers $\left({ }^{14} \mathrm{C},{ }^{18} \mathrm{O},{ }^{2} \mathrm{H}\right)$ was used to determine the residence time of groundwater and to document climate fluctuations, while dissolved noble gases were used to estimate mean annual temperatures (noble gas recharge temperatures, NGRT) at the water table. Near-surface ground temperature reconstruction from $40 \mathrm{ka}$ cal BP to the present was made using data collected from five aquifers. The coldest temperatures are recorded for late Marine Isotopic Stage (MIS) 3 and MIS 2, i.e. between 36 and $18 \mathrm{ka}$ cal BP. The mean NGRT for the period $27-18 \mathrm{ka} \mathrm{cal} \mathrm{BP}$ is estimated at $5.9 \pm 0.9^{\circ} \mathrm{C}$, and a strong increase towards modern values $\left(11-13{ }^{\circ} \mathrm{C}\right)$ is observed after $15 \mathrm{ka}$ cal BP. The temperature change between the Holocene and the Last Glacial ranges from 5 to $7^{\circ} \mathrm{C}$, in agreement with previous NGRT studies in Europe. Since mean nearsurface ground temperatures during the glacial were well above $0{ }^{\circ} \mathrm{C}$, long-term presence of permafrost in northern Aquitaine is unlikely. However, a possible warm bias in reconstructed temperatures during the coldest events lies in the fact that NGRTs in cold regions do not reflect annual means but rather the ground temperature during the thaw months.
\end{abstract}

Keywords Stable isotopes $\cdot$ Groundwater age $\cdot$ Paleohydrology $\cdot$ Groundwater recharge $\cdot$ France

\section{Introduction}

Multi-layer aquifer systems are an important strategic water resource. In order to manage properly those resources, a good

Marc Saltel

m.saltel@brgm.fr

1 BRGM Nouvelle Aquitaine, Parc Technologique Europarc, 24, Avenue Léonard de Vinci, 33600 Pessac, France

2 University of Bordeaux, CENBG, 19 Chemin du Solarium - CS 10120, 33175 Gradignan Cedex, France

3 CNRS (UMR 5797) CENBG, 19 Chemin du Solarium - CS 10120 , 33175 Gradignan Cedex, France

4 Bordeaux INP, G\&E, EA 4592, 33600 Pessac, France

5 Université Bordeaux Montaigne, G\&E, EA 4592, 33600 Pessac, France

6 Inrap, 140 Avenue du Maréchal Leclerc, 33130 Bègles, France

7 PACEA, University of Bordeaux-CNRS, allée Geoffroy-Saint-Hilaire, 33615 Pessac, France knowledge of the systems is needed. The Aquitaine basin in southwest France is a large multi-layer aquifer system where groundwater has residence times from a few years or decades to thousands of years (Chery et al. 1994). Since present groundwater is inherited from former aquifer recharge, which occurred under changing climate conditions (Schoeller 1971), this residence time variability gives the opportunity to use the aquifers as paleoclimate archives for this timespan (Fontes et al. 1993). Comparison of isotopic data sampled in north European aquifers suggested a "recharge gap" during part of the Last Glacial, which was attributed to the presence of permafrost or to low atmospheric moisture supply (Darling 2004). Because permafrost acted as an impermeable layer, groundwater movement was restricted to few favourable areas such as unfrozen ground (taliks) below lakes or large rivers (Ford 1993; French 2007) and, therefore, led to strong reduction of aquifer recharge (Vidstrand 2003). Groundwater analysis may thus provide a useful tool for paleopermafrost reconstruction. In southwest France, the presence of late Pleistocene permafrost and its extension is a matter of debate. According to the available studies, permafrost was supposed to range 


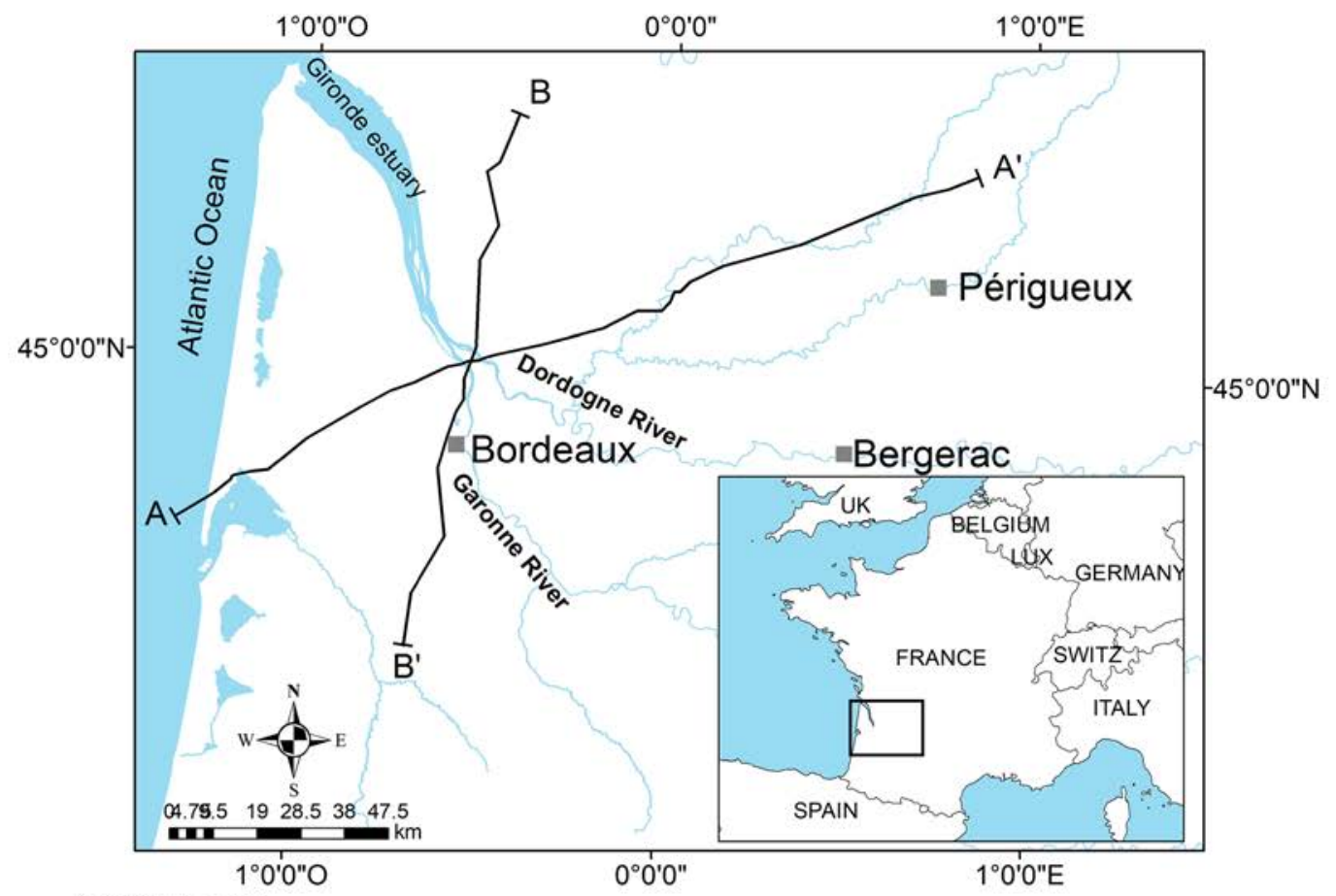

(a) Study area

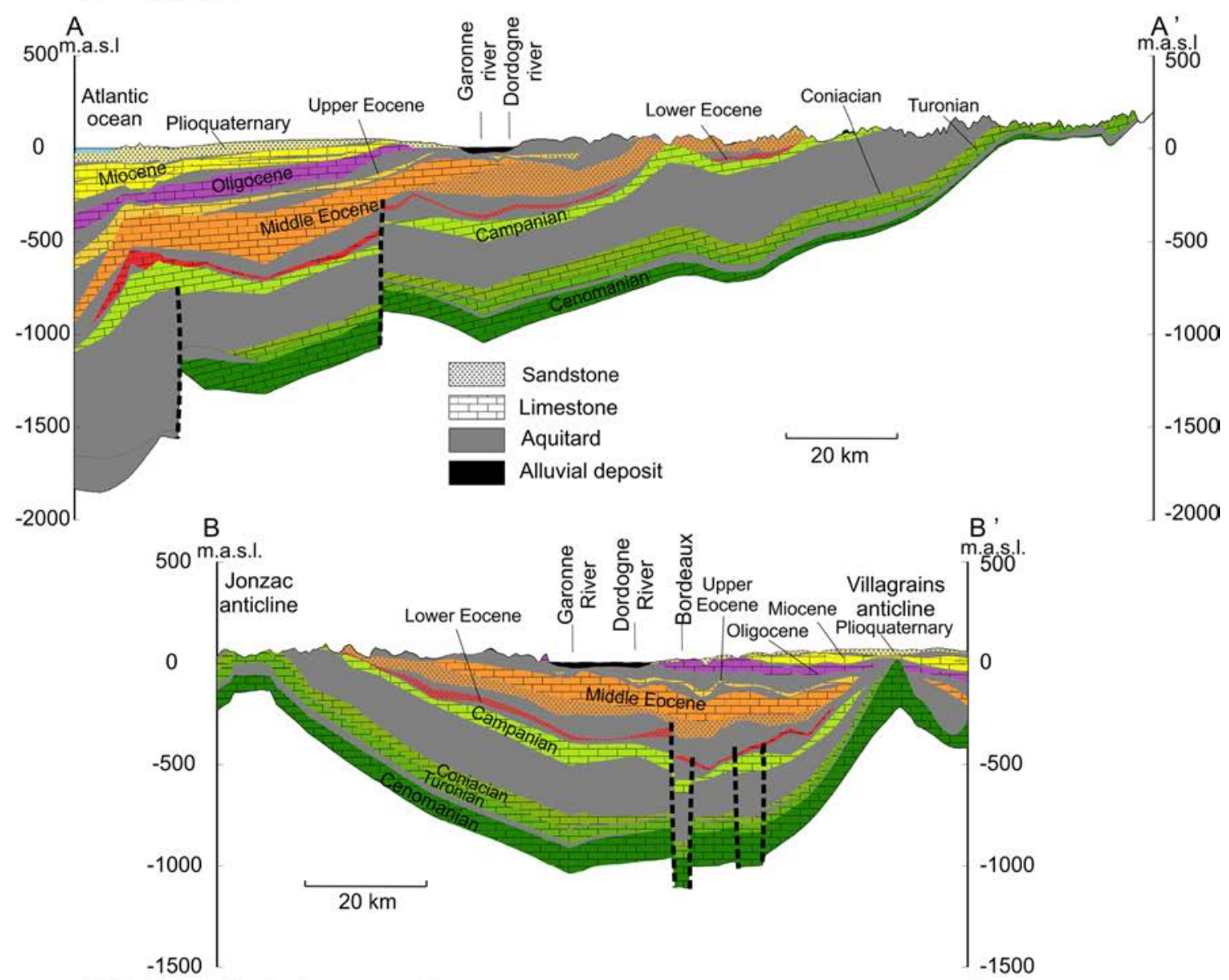

(b) Hydrogeological cross sections

Fig. 1 a Location and $\mathbf{b}$ hydrogeological cross sections of the North Aquitaine Basin (southwest France) 
from continuous to nearly absent during the coldest events of the glacial period.

The purpose in the present study is to investigate this question through analyses of groundwater sampled in the northern part of the Aquitaine basin. Natural isotopic tracers have been used to determine the groundwater residence time $\left({ }^{14} \mathrm{C}\right)$, and to highlight the paleoclimate fluctuations $\left({ }^{18} \mathrm{O},{ }^{2} \mathrm{H}\right)$. Noble gas measurements ( $\mathrm{He}, \mathrm{Ne}, \mathrm{Ar}, \mathrm{Kr}, \mathrm{Xe}$ ) were used to determine the mean annual temperature at the water table. Temperature records and associated groundwater ages allow for paleoclimate reconstruction in the study area, whereby a comparison with other regional proxies is then proposed.

\section{Hydrogeological and paleoclimatic context}

\section{Hydrogeological context}

The study region is located in the northern part of the Aquitaine basin, southwest France (Fig. 1). The basin is filled with Mesozoic and Cenozoic sedimentary deposits of contrasting lithologies and permeabilities, thus creating a multilayer aquifer system with alternating aquifers and aquitards. This system is bounded by two major anticlines: Jonzac to the north and Villagrains to the south (Gély and Sztrakos 2000). The various aquifers of this system are of uneven extensions and can be subdivided into two groups:

1. The Upper Cretaceous multi-layer system mainly composed of fissured limestone, in which four aquifers can be defined including (from the deeper to the shallower): Cenomanian, Turonian, Coniacian and Campanian. In some areas, the aquifers are not separated by a significant aquitard and, thus, form a single reservoir. This is particularly the case underneath the city of Bordeaux where Cenomanian, Turonian and Coniacian deposits are part of a combined reservoir composed of cemented siliceous sandstone overlain with limestone and dolomitic limestone (Pédron et al. 2008). The range of transmissivity reported in the literature is between $3 \cdot 10^{-3}$ and 6 . $10^{-3} \mathrm{~m}^{2} / \mathrm{s}$ (Gombert 1988). The upper aquitard consists of compact chalky marl, ca. 200-300 m thick. The karstic Campanian aquifer is formed by bioclastic limestone and sandy limestone of low interstitial porosity balanced by a large fracture porosity.

2. The Cenozoic complex is composed of six aquifers: lower Eocene, middle Eocene, upper Eocene, Oligocene, Miocene and Plio-Quaternary. Because of their accessibility, they are currently widely exploited. The middle Eocene aquifer is the main reservoir; it shows strong lateral lithofacies variations from sandy alluvial deposits to the east to shallow marine limestones to the west. Thus, two major ranges of transmissivity can be identified, the first around $5 \cdot 10^{-4} \mathrm{~m}^{2} / \mathrm{s}$ corresponding to sandy layers and the second around $2 \cdot 10^{-3} \mathrm{~m}^{2} / \mathrm{s}$ corresponding to limestones (Larroque 2004). The aquifer is overlaid by a 50 m-thick aquitard composed of marl and clay. The Oligocene aquifer comprises mainly limestone. Most of the measurements show transmissivity values between 1 . $10^{-3}$ and $6 \cdot 10^{-3} \mathrm{~m}^{2} / \mathrm{s}$. Like the middle Eocene aquifer, this Oligocene limestone aquifer is widely used for drinking water. The Miocene aquifer is composed of sandstone and is mainly used for irrigation, as is the Plio-Quaternary aquifer, which corresponds to a shallow system within alluvial or eolian gravel and sand formations.

On a large scale, groundwater in the north-Aquitaine multilayer system flows toward the Gironde estuary, which constitutes a drainage area for the deeper aquifers. West of the estuary, flow occurs from a high piezometric area westwards to the ocean on the one hand and eastward to the Gironde estuary on the other hand. The leakage exchange flows between the aquifers through the aquitards are mainly downwards in the eastern part of the basin and are more complicated in the rest of the basin, with fluxes both upwards and downwards according to local piezometric conditions (Larroque et al. 2008).

\section{Paleoclimatic context}

Across Western Europe, major climate changes occurred during the late Pleistocene and are well-documented by a large array of data, both in continental (Fletcher et al. 2010; Genty et al. 2010) and marine settings (Eynaud et al. 2012). These changes involved significant variation in precipitation and groundwater recharge (Jiráková et al. 2011). Available studies show a contrast in the rate of groundwater recharge between northern and southern Europe (Bath et al. 1979; Celle-Jeanton et al. 2009; Deák et al. 1987; Dray et al. 1997; Geyer et al. 1993; Geyh et al. 1984; Huneau et al. 2001). A gap in recharge, which lasted some millennia to tens of millennia, typifies the northern catchments and is assumed to reflect permafrost development during the coldest part of the glacial. Data on southwest France remain scarce so far, but suggest groundwater recharge to have taken place continuously. In contrast, the speleothem records from Villars Cave, northern Aquitaine, point to a stop in stalagmite growth between $\sim 30$ to $\sim 16 \mathrm{ka}$ (Genty et al. 2003, 2006, 2010). As indicated by isotopic data, this gap corresponds to a strong cooling and, therefore, was thought to reflect restricted water percolation through the host limestone due to permafrost.

Features such as ice-wedge pseudomorphs and the remnants of other ground ice bodies provide another line of evidence for the existence of Pleistocene permafrost in France. The studies on their distribution show that a large part of the territory was affected by permafrost (Van Vliet-Lanoë 1989, 1996; Texier 1996; Vandenberghe et al. 2014; Andrieux et al. 
Fig. 2 Location of the sampling sites

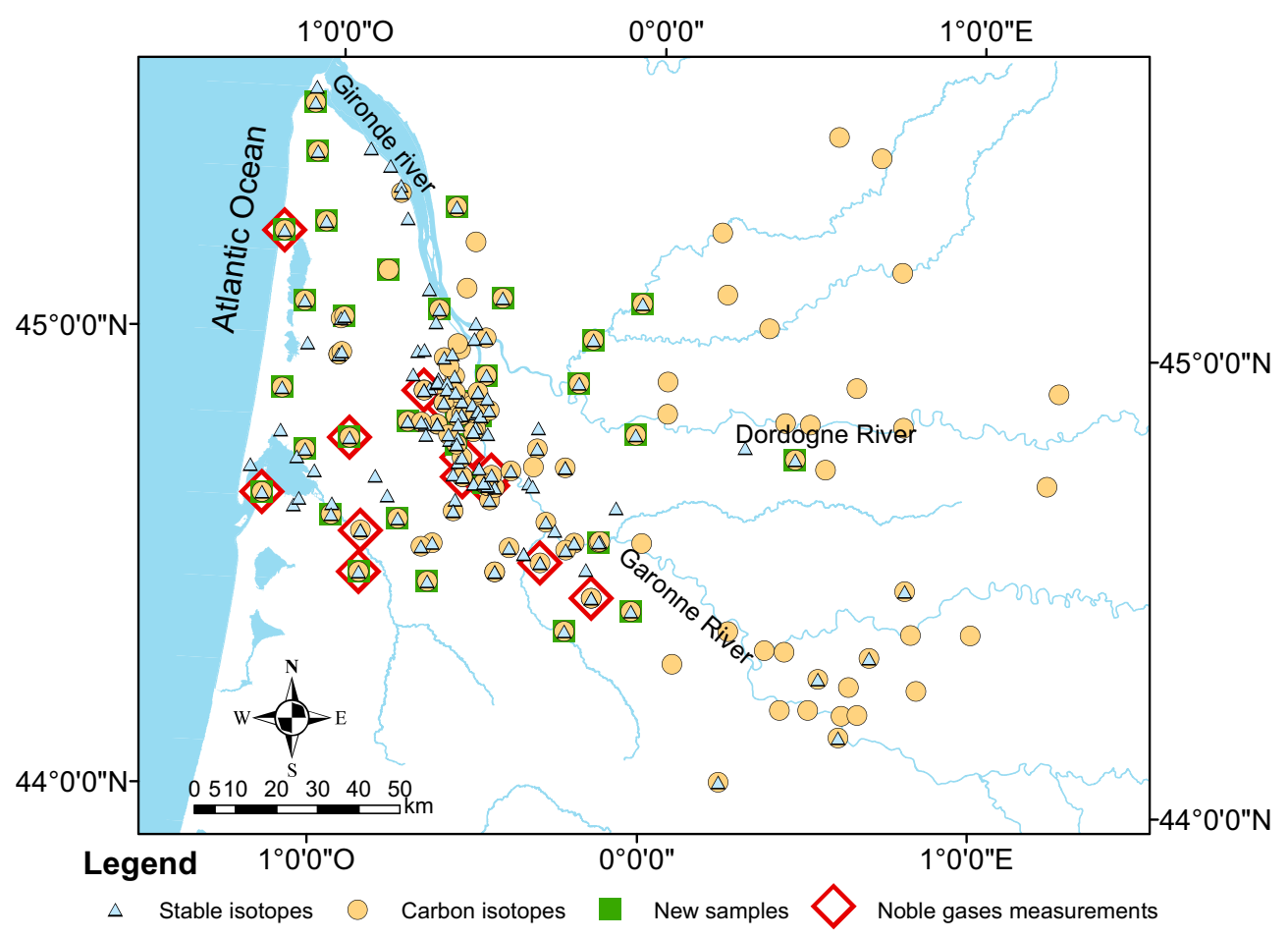

A similar mismatch between simulated temperatures and those provided by vegetation is also underlined by Kageyama et al. (2006) and Ramstein et al. (2007).

\section{Materials and methods}

\section{Sampling strategy}

Although groundwater can be used as a paleoclimate recorder, several phenomena such as leakage between aquifers or molecular diffusion in stagnant groundwater bodies may smooth the record of climate variations. In addition, modeled ages are associated with a large uncertainty for the oldest groundwater (Fontes et al. 1993). As a consequence, only major events have a significant impact on the isotopic signal carried by water molecules, and any climatic fluctuation lasting less than a thousand years is assumed not to be detectable (Stute and Schlosser 1993). Establishing a sampling strategy appropriate to the local context is of prime importance to reduce as far as possible the uncertainties on climate reconstruction. Nevertheless, only a combination of methods is able to provide robust information on past climate changes and their potential impacts on groundwater.

A total of 36 new water samples were collected for ${ }^{14} \mathrm{C}$ dating and measurement of stable isotopes (Fig. 2). The samples were taken in five aquifers to obtain a wide range of residence times. Indeed, according to the Tóth theoretical diagram (Tóth 1995), the residence time increases with depth. 
These new data add to measurements made within the framework of previous studies (Hosteins 1982; Chery 1993; Chery et al. 1994; Chery and Gadalia 2001; Bonnery et al. 1994; Platel et al. 1999; Schnebelen et al. 2002; Franceschi 2005; Saltel 2008; Malcuit 2012). A total of 120 samples were used to obtain corrected ages to give an overview of the distribution of residence times in the multi-layered aquifer system. Furthermore, 138 measurements of $\delta^{18} \mathrm{O}$ and $\delta^{2} \mathrm{H}$ have been used to document the isotopic composition of groundwater. Among these samples, 17 samples collected in 14 wells were analyzed for noble gases. The aim of the borehole selection for sampling was to obtain a paleotemperature data set covering the whole age range of groundwater that can be found in northern Aquitaine. Thus, seven samples were retrieved from the Oligocene aquifer, four from the Eocene, one from the Aquitanian and two from the Campanian.

\section{Analytical methods}

Physical parameters such as electrical conductivity (EC), temperature $(\mathrm{T})$ and $\mathrm{pH}$ were measured directly in the field using a WTW 3310 multiparameter gauge.

\section{Water stable isotopes}

Major element concentrations and water stable isotopes were analyzed at the laboratory EA 4592 "Géoressources et Environnement" at the Institut Polytechnique at Bordeaux (Bordeaux-INP). Groundwater samples were filtered through $0.45-\mu \mathrm{m}$ membranes and stored in polyethylene bottles for major elements, and collected in amber glass bottles for stable isotopes. All samples were stored at $4{ }^{\circ} \mathrm{C}$ until analysis. The major ion concentrations were determined by highperformance liquid chromatography using a Dionex 320 chromatograph (IonPac CS16) for cations and a Dionex 1100 chromatograph (IonPac AS9-HC) for anions. The stable isotope analyses were performed using a liquid-water stable isotope analyzer DLT-100 Los Gatos Research according to the analytical scheme recommended by the IAEA (Aggarwal et al. 2009; Penna et al. 2010). The quality of the isotopic analysis was checked using a standard deviation condition up to 1 for $\delta \mathrm{D}$ and up to 0.1 for $\delta^{18} \mathrm{O}$ for six analyses of the same sample.

\section{Carbon isotopes}

The ${ }^{14} \mathrm{C}$ and ${ }^{13} \mathrm{C}$ composition of the groundwater samples was measured at the University of Waterloo-Environmental Isotope Laboratory (Canada) and the Rafter Radiocarbon Laboratory (New Zealand) using the AMS usual protocols. The radiocarbon activities are expressed as percent modern $\mathrm{C}$ (pmc), and the isotopic $\delta{ }^{13} \mathrm{C}$ values are reported in the conventional notation "per mil" as a deviation from the VSMOW (Vienna Standard Mean Ocean Water) for water and PDB (American Belemnitella from the Pee Dee formation, North Carolina, USA) for carbonate and total dissolved inorganic carbon (TDIC).

\section{Noble gases}

Noble gases are considered as efficient hydrological tracers since they are not sensitive to their close environment. Chemically inert, they are not involved in chemical reaction or biological activity. The dissolved noble gases in groundwater have mainly an atmospheric origin. Their concentration in solution results from physico-chemical equilibriums with their atmospheric component according to Henry's law, and depend on the physical conditions (temperature, salinity and pressure which is linked to altitude) prevailing in the recharge area during water infiltration. Once the saturated zone is reached, the atmospheric component of the dissolved noble gases is generally preserved and allows the determination of the ground temperature at the water table, which reflects the mean surface temperature at the time of recharge (Beyerle 1999; Aeschbach-Hertig et al. 1999; Aeschbach-Hertig and Solomon 2013; Stute and Schlosser 1993; Seltzer et al. 2015).

To these dissolved initial concentrations is added an atmospheric component due to the presence of small air bubbles trapped during water infiltration, referred to as "excess air" (Heaton and Vogel 1981; Beyerle 1999). A radiogenic component has also to be considered. Some radiogenic isotopes are produced within the minerals in the host rocks and are partially released in groundwater. The main radiogenic isotopes to be considered are ${ }^{4} \mathrm{He}$ and ${ }^{40} \mathrm{Ar}$ produced respectively by the radioactive decay of $\mathrm{U}$, Th and ${ }^{40} \mathrm{~K}$. Finally, in some deep aquifers, a diffusive component arising from the continental crust or the mantle can be observed (Beyerle 1999); whereby simultaneous analysis of five noble gases $(\mathrm{He}, \mathrm{Ne}, \mathrm{Ar}, \mathrm{Kr}, \mathrm{Xe})$ in groundwater allows better determination of their origin.

Noble gas measurements were performed at the Centre d'Etudes Nucléaires de Bordeaux Gradignan (CENBG). To avoid air contamination or degassing, the water sample was transferred through a short plastic tube as soon as possible from the sampling tap to an airtight container. Around $28 \mathrm{~cm}^{3}$ of water was sampled in a pure copper tube held on an aluminum rack. Stainless steel clamps placed at each end of the support crimp the tube to insure sample airtightness. A third clamp located in the middle of the rack allowed splitting the water sample into two sub-samples of $14 \mathrm{~cm}^{3}$ each. Prior to its closure, the copper tube was rinsed thoroughly for few minutes to avoid air bubbles being trapped with the sample. At the laboratory, gas extraction of the water sample was performed by connecting the copper tube directly to a high vacuum extraction line. By opening a clamp of the sampler, water flowed into an expansion vessel. Gases were extracted by gentle agitation of the vessel for at least $1 \mathrm{~h}$ and then they were transferred to a purification line by means of a capillary 


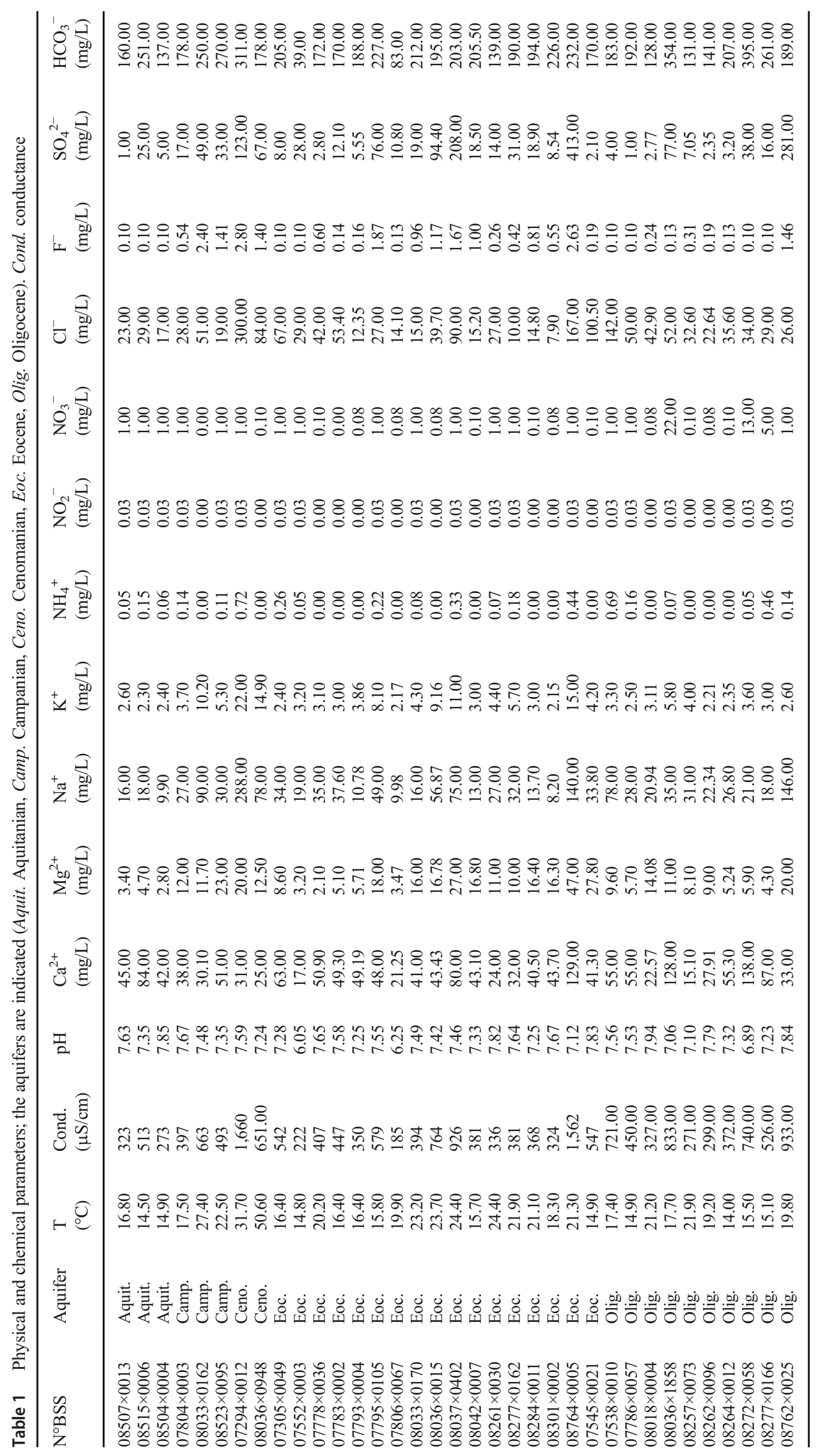


Table 2 Physical and chemical parameters of water samples from older studies - sampling points for noble gases (Camp. Campanian, Eoc. Eocene, Olig. Oligocene). Cond. conductance

\begin{tabular}{lllllllllllll}
\hline $\mathrm{N}^{\circ} \mathrm{BSS}$ & Aquifer & $\begin{array}{l}\mathrm{T} \\
\left({ }^{\circ} \mathrm{C}\right)\end{array}$ & $\begin{array}{l}\text { Cond. } \\
(\mu \mathrm{S} / \mathrm{cm})\end{array}$ & $\mathrm{pH}$ & $\begin{array}{l}\mathrm{Ca}^{2+} \\
(\mathrm{mg} / \mathrm{L})\end{array}$ & $\begin{array}{l}\mathrm{Mg}^{2+} \\
(\mathrm{mg} / \mathrm{L})\end{array}$ & $\begin{array}{l}\mathrm{Na}^{+} \\
(\mathrm{mg} / \mathrm{L})\end{array}$ & $\begin{array}{l}\mathrm{K}^{+} \\
(\mathrm{mg} / \mathrm{L})\end{array}$ & $\begin{array}{l}\mathrm{Cl}^{-} \\
(\mathrm{mg} / \mathrm{L})\end{array}$ & $\begin{array}{l}\mathrm{SO}_{4}{ }^{2-} \\
(\mathrm{mg} / \mathrm{L})\end{array}$ & $\begin{array}{l}\mathrm{F}^{-} \\
(\mathrm{mg} / \mathrm{L})\end{array}$ \\
\hline $08763 \times 0017$ & Olig. & 17.3 & 711 & 7.53 & 53.41 & 32.13 & 55.14 & 5.02 & 59.29 & 16.92 & 0.35 \\
$(\mathrm{mg} / \mathrm{L})$
\end{tabular}

tube. The latter allowed recovery of almost all the extracted gases while limiting vapor transfer (Osenbrück et al. 1998; Beyerle et al. 2000). Helium and neon were cryogenically separated from the other noble gases by means of activated charcoal at the temperature of liquid nitrogen that traps the condensable gaseous phases (mainly water vapor and heavy noble gases: Ar, $\mathrm{Kr}$ and $\mathrm{Xe}$ ). Getters composed of titanium sponge allowed purification of the phase of light noble gases $(\mathrm{He}, \mathrm{Ne})$. The phase of heavy noble gases was first exposed to zeolites traps to eliminate water prior to exposure to the getters. After cryogenic separation from the heavy noble gases, $\mathrm{He}$ and Ne were introduced into a VG Micromass 1200 mass spectrometer for isotopic analysis. $\mathrm{Ar}, \mathrm{Kr}$, and $\mathrm{Xe}$ were also cryogenically separated and successively introduced into the mass spectrometer. Absolute concentrations were determined using an isotopic dilution method with two specially prepared noble gas spikes. The precision on measured concentrations

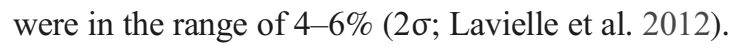

Fig. 3 Groundwater cation and anion composition plotted in a Piper diagram

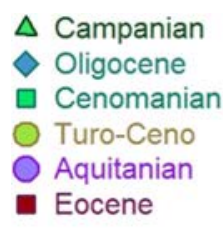




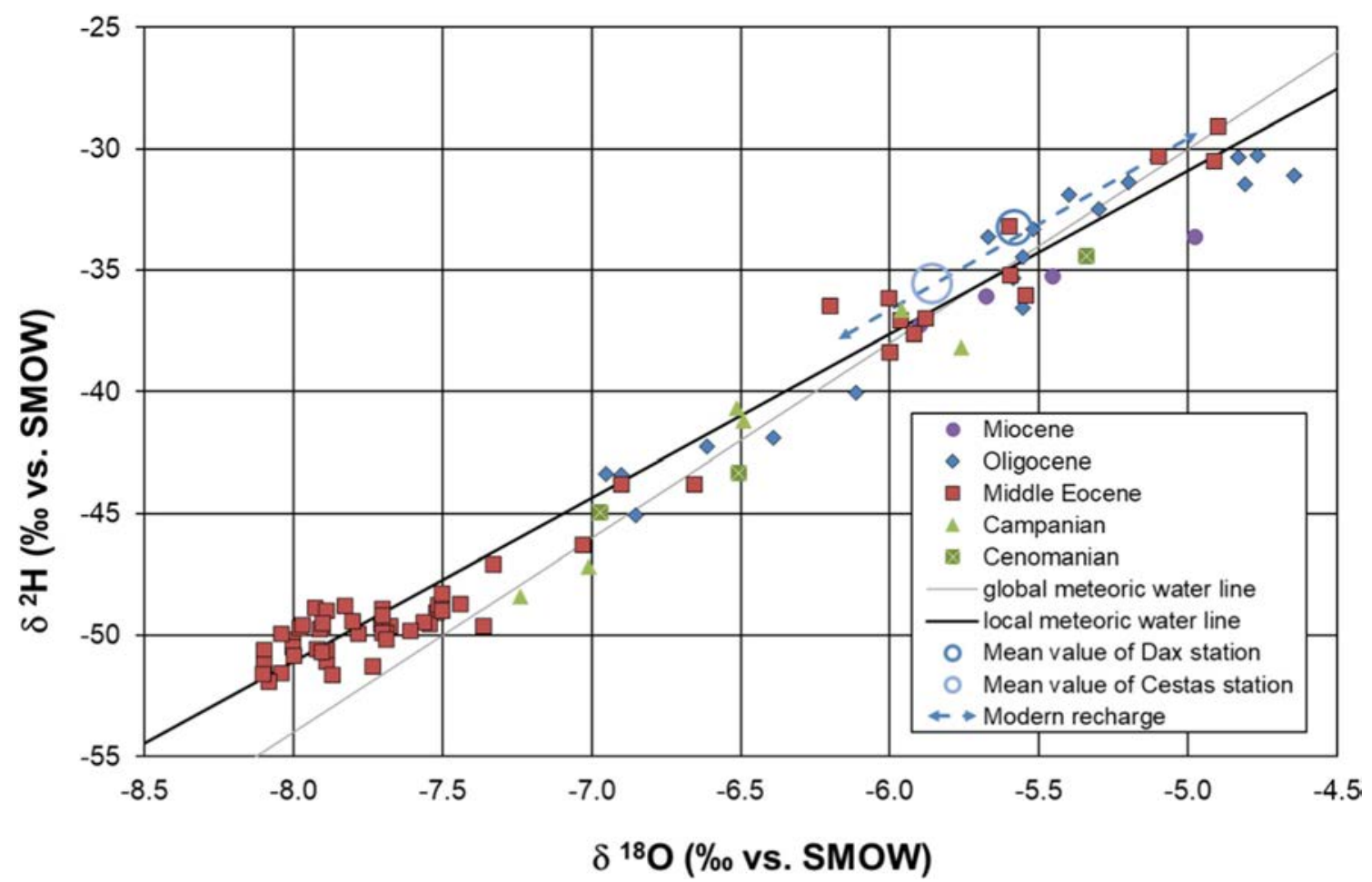

Fig. 4 Plot of $\delta^{18} \mathrm{O}$ vs. $\delta^{2} \mathrm{H}$ of groundwater collected in the North Aquitaine multi-layer aquifer system; annual weighted mean for the Cestas and the Dax Station (Millot et al. 2010)

\section{Results}

\section{Major elements}

The geochemical water-type of the samples is mainly bicarbonate-calcic (Tables 1 and 2). Water sampled in the early and middle Eocene aquifers is more mineralized and has variable content in sulfates and chlorides (Fig. 3). Oligocene groundwater, showing limited mineralization, has a bicarbonate-calcic water-type. Upper Cretaceous (Santonian-Campanian) water is also little mineralized, while most of the Cretaceous samples have a bicarbonate calcic type.

The groundwater samples from the early and middle Eocene aquifers are the more scattered and the Piper diagram highlights a clear trend. The processes involved in the acquisition of mineralization are complex and seem to occur in two steps (Malcuit et al. 2014). Firstly, the processes of water-rock interaction in a carbonate system give water its mineralization, as shown by the bicarbonate-calcic water-type of the low mineralized samples, and secondly, water is increasingly enriched in dissolved elements, especially sulfates and chlorides mainly provided by evaporite dissolution (Malcuit et al. 2014). During evaporite dissolution, sulfate, fluoride and calcium are released and the water becomes over-saturated with respect to calcite which precipitates, leading to a decrease of the $\mathrm{HCO}_{3}{ }^{-}$concentration and an increase in $\mathrm{pH}$. Some water exceeds the standard of sulfates concentration for drinking water $(250 \mathrm{mg} / \mathrm{L})$. The others aquifers sampled do not show any similar trend.

\section{Stable isotopes}

Water $\delta^{18} \mathrm{O}$ and $\delta^{2} \mathrm{H}$ values range from -7.88 to $-4.64 \%$ and from -51.65 to $-30.28 \%$ respectively. These results are in good agreement with previous analyses, which yielded $\delta^{18} \mathrm{O}$ values from -8.1 to $-3.7 \%$ and $\delta^{2} \mathrm{H}$ values from -51.9 to $-21.6 \%$ (Hosteins 1982; Chery 1993; Chery et al. 1994; Chery and Gadalia 2001; Bonnery et al. 1994; Platel et al. 1999; Schnebelen et al. 2002; Franceschi 2005; Saltel 2008; Malcuit 2012).

All samples almost fit the Global Meteoric Water Line (Fig. 4). Two International Atomic Energy Agency (IAEA) stations are located near the study area: the Cestas station and the Dax station (IAEA 2018). The Cestas station covers the most recent and complete period (2007-2016). A local meteoric line has been established from these measurements. The best fit is obtained between this local line and groundwater measurements. The depletion in ${ }^{2} \mathrm{H}$ and ${ }^{18} \mathrm{O}$ relative to other samples is associated with low ${ }^{14} \mathrm{C}$ content, i.e. with old ages and, therefore, points to the cooler climate of the Last Glacial. The most depleted water samples come from the middle Eocene aquifer and show a strong deuterium excess, while water from the other aquifers is less depleted. 


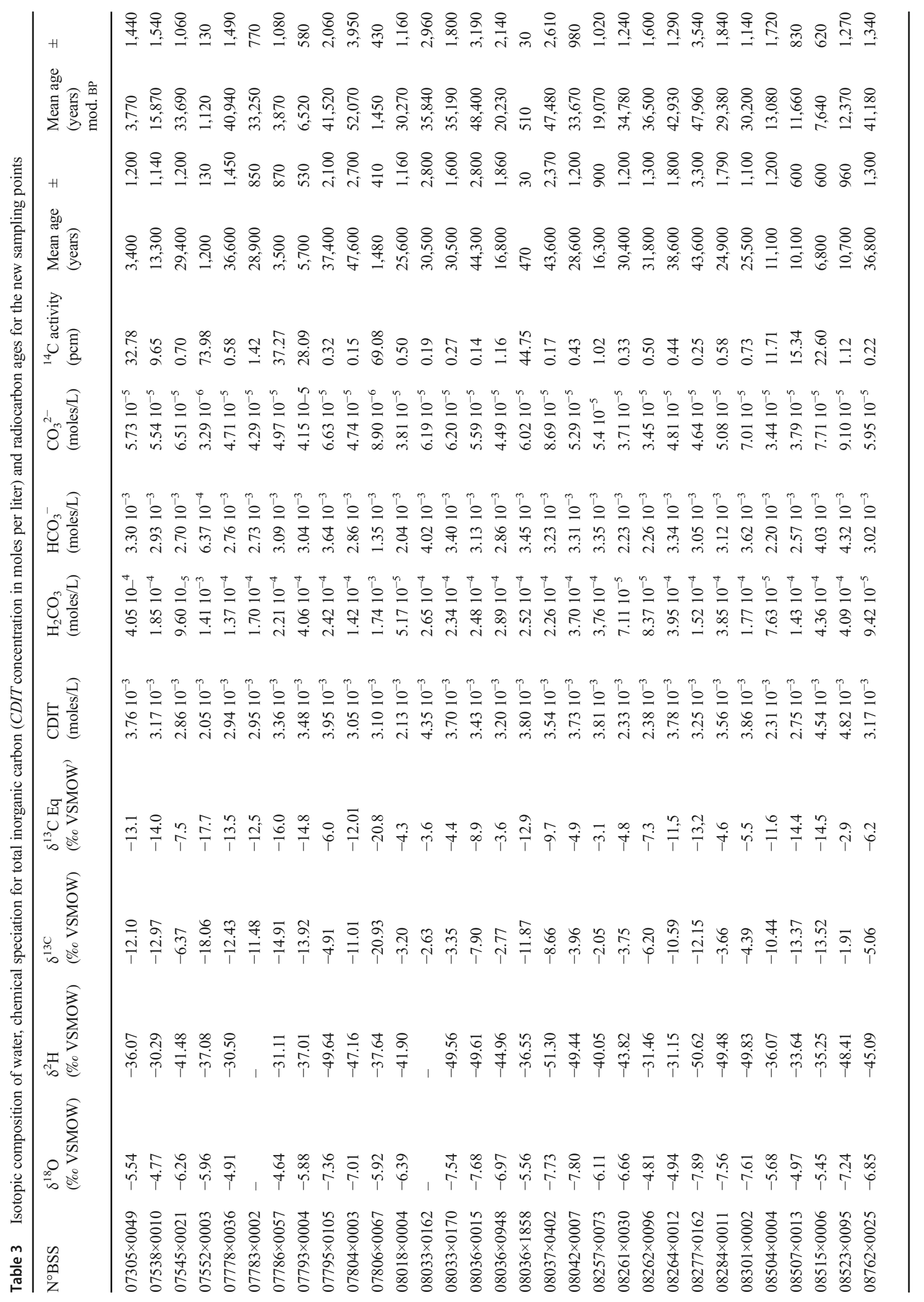


Table 4 Isotopic composition of water and radiocarbon ages for older studies (sampling points for noble gases)

\begin{tabular}{llllllll}
\hline $\mathrm{N}^{\circ} \mathrm{BSS}$ & $\begin{array}{l}\delta^{18} \mathrm{O} \\
(\% \text { VSMOW })\end{array}$ & $\begin{array}{l}\delta^{2} \mathrm{H} \\
(\% \text { VSMOW })\end{array}$ & $\begin{array}{l}\delta^{13} \mathrm{C} \\
(\% \text { VSMOW })\end{array}$ & $\begin{array}{l}{ }^{14} \mathrm{C} \text { activity } \\
(\mathrm{pcm})\end{array}$ & $\begin{array}{l}\text { Mean age } \\
\text { (years })\end{array}$ & $\begin{array}{l}\text { Mean age (years) } \\
\text { mod. BP }\end{array}$ \\
\hline $08763 \times 0017$ & -6.95 & -43.38 & -12.48 & 2.77 & 22,800 & 2,000 & 27,160 \\
$08035 \times 0360$ & -5.59 & -34.51 & -12.25 & 22.33 & 6,300 & 350 & 7,130 \\
$08276 \times 0091$ & -5.20 & -31.37 & -12.09 & 3.01 & 21,600 & 2,400 & 25,900 \\
$08035 \times 0465$ & -5.38 & -33.65 & -10.45 & 16.37 & 7,500 & 300 & 8,370 \\
$08525 \times 0028$ & -6.90 & -43.40 & -7.27 & 3.31 & 17,700 & 370 & 21,230 \\
$08277 \times 0215$ & -7.92 & -50.58 & -7.30 & 0.90 & 28,300 & 550 & 32,840 \\
$08272 \times 0136$ & -6.49 & -41.19 & -6.33 & 3.06 & 20,000 & 650 & 23,790 \\
\hline
\end{tabular}

\section{Carbon isotopes}

The $\delta^{13} \mathrm{C}$ value of the TDIC (Tables 3 and 4) range from -20.93 to $-1.91 \%$ o vs PDB $(-12.48$ to $-6.33 \%$ o for older analyses). ${ }^{14} \mathrm{C}$ values range from 0.14 to $74 \mathrm{pmc}$.

In a carbonate aquifer, the $\delta^{13} \mathrm{C}$ value of the TDIC results from the following:

1. Isotopic equilibrium with biogenic $\mathrm{CO}_{2}$ (open system with respect to soil $\mathrm{CO}_{2}$ ) during mineralization, or

2. Partial isotopic mixing between biogenic $\mathrm{CO}_{2}$ and the limestone matrix (closed system for soil $\mathrm{CO}_{2}$ ). In this study, the $\delta^{13} \mathrm{C}$ content of the biogenic $\mathrm{CO}_{2}$ is considered to be about $-21 \%$, which is characteristic of the natural C-3 vegetation under temperate climate (Deines et al. 1974).
In order to assess the system in which $\mathrm{C}$ evolves, a calculation of $\delta^{13} \mathrm{C}_{\text {gas }}$ eq, i.e. $\delta^{13} \mathrm{C}$ of the gaseous phase in equilibrium with the measured TDIC, was carried out using the following equation (Le Gal La Salle et al. 1996):

$\delta^{13} \mathrm{C}_{\text {gas } \_ \text {eq }}=\delta^{13} \mathrm{C}-\frac{\left|\mathrm{CO}_{2}\right| \varepsilon_{\mathrm{CO}_{2}-\mathrm{g}}+\left|\mathrm{HCO}_{3}^{-}\right| \varepsilon_{\mathrm{HCO}_{3}^{-}-\mathrm{g}}+\left|\mathrm{CO}_{3}^{2-}\right| \varepsilon_{\mathrm{CO}_{3}^{2-}-\mathrm{g}}}{C_{\mathrm{tot}}}(1)$

where $\epsilon$ is enrichment factor between carbon species and the gas phase g; and $C_{\text {tot }}$ is total of carbon species.

The distribution of the carbon species is determined using the geochemical software PHREEQC 3.0 (Parkhurst and Appelo 2013). The calculated $\delta^{13} \mathrm{C}_{\text {gas_eq }}$ varies from -2.9 to $-20.8 \%$ o (Tables 3 and 4 ). Therefore,
Table 5 Concentrations of dissolved noble gases in groundwater (expressed in $10^{-7} \mathrm{~cm}^{3} \mathrm{STP} / \mathrm{g}$ water). The aquifers are indicated (Olig. Oligocene, Eoc. Eocene, Camp Campanian, Aquit. Aquitanian)

\begin{tabular}{lllllll}
\hline Site & Aquifer & $\begin{array}{l}\mathrm{He} \\
\left(10^{-7} \mathrm{~cm}^{3}\right.\end{array}$ & $\begin{array}{l}\mathrm{Ne} \\
\left(10^{-7} \mathrm{~cm}^{3}\right.\end{array}$ & $\begin{array}{l}\mathrm{Ar} \\
\left(10^{-7} \mathrm{~cm}^{3}\right.\end{array}$ & $\begin{array}{l}\mathrm{Kr} \\
\left(10^{-7} \mathrm{~cm}^{3}\right.\end{array}$ & $\begin{array}{l}\mathrm{Xe} \\
\mathrm{STP} / \mathrm{g} \text { water })\end{array}$ \\
& & $\mathrm{STP} / \mathrm{g}$ water $)$ & $\mathrm{STP} / \mathrm{g}$ water $)$ & $\mathrm{STP} / \mathrm{g}$ water $)$ & $\mathrm{STP} / \mathrm{g}$ water $)$ \\
\hline $08257 \times 0073$ & Olig. & $2.57 \pm 0.32$ & $2.59 \pm 0.11$ & $4,546 \pm 257$ & $1.00 \pm 0.05$ & $0.151 \pm 0.007$ \\
$08763 \times 0017$ & Olig. & $10.6 \pm 0.75$ & $2.42 \pm 0.10$ & $4,594 \pm 277$ & $1.03 \pm 0.05$ & $0.148 \pm 0.006$ \\
$08262 \times 0096 / \mathrm{F}$ & Olig. & $0.86 \pm 0.07$ & $2.42 \pm 0.17$ & $4,535 \pm 281$ & $0.95 \pm 0.06$ & $0.138 \pm 0.006$ \\
$07538 \times 0010$ & Olig. & $0.99 \pm 0.07$ & $2.37 \pm 0.10$ & $4,470 \pm 280$ & $1.02 \pm 0.05$ & $0.136 \pm 0.006$ \\
$08276 \times 0091$ & Olig. & $0.92 \pm 0.21$ & $2.61 \pm 0.11$ & $4,370 \pm 280$ & $0.97 \pm 0.06$ & $0.129 \pm 0.006$ \\
$08503 \times 0010$ & Olig. & $0.45 \pm 0.29$ & $2.60 \pm 0.13$ & $4,298 \pm 244$ & $0.93 \pm 0.05$ & $0.122 \pm 0.005$ \\
& & $0.82 \pm 0.19$ & $2.55 \pm 0.13$ & $4,232 \pm 238$ & $0.92 \pm 0.05$ & $0.119 \pm 0.005$ \\
$08525 \times 0028$ & Olig. & $15.2 \pm 1.15$ & $2.66 \pm 0.16$ & $4,472 \pm 276$ & $1.07 \pm 0.06$ & $0.150 \pm 0.006$ \\
& & $16.0 \pm 1.13$ & $2.67 \pm 0.14$ & $4,685 \pm 296$ & $1.07 \pm 0.07$ & $0.150 \pm 0.007$ \\
$08277 \times 0215$ & Eoc. & $18.8 \pm 1.33$ & $2.32 \pm 0.10$ & $4,339 \pm 272$ & $0.98 \pm 0.05$ & $0.138 \pm 0.006$ \\
$08277 \times 0152$ & Eoc. & $17.7 \pm 1.25$ & $2.33 \pm 0.10$ & $4,390 \pm 258$ & $0.99 \pm 0.06$ & $0.138 \pm 0.006$ \\
$08035 \times 0393$ & Eoc. & $90.1 \pm 7.28$ & $2.41 \pm 0.30$ & $4,740 \pm 266$ & $1.06 \pm 0.06$ & $0.151 \pm 0.007$ \\
$07792 \times 0006$ & Eoc. & $0.83 \pm 0.14$ & $2.92 \pm 0.20$ & $4,607 \pm 336$ & $1.02 \pm 0.06$ & $0.135 \pm 0.005$ \\
$08514 \times 0047$ & Camp. & $0.61 \pm 0.08$ & $2.54 \pm 0.28$ & $4,207 \pm 262$ & $0.93 \pm 0.05$ & $0.128 \pm 0.06$ \\
$08272 \times 0136$ & Camp. & $5.67 \pm 0.40$ & $2.53 \pm 0.23$ & $4,926 \pm 274$ & $1.13 \pm 0.06$ & $0.157 \pm 0.007$ \\
& & $5.38 \pm 0.38$ & $2.42 \pm 0.12$ & $4,757 \pm 292$ & $1.08 \pm 0.06$ & $0.154 \pm 0.006$ \\
$08507 \times 0013$ & Aquit. & $1.19 \pm 0.23$ & $2.69 \pm 0.12$ & $4,451 \pm 273$ & $0.94 \pm 0.06$ & $0.135 \pm 0.007$ \\
\hline & & & & & &
\end{tabular}


Table 6 Salinity measurements and atmospheric pressure at the sampling points, and outputs of the Closed System Equilibration Model (Noble90 software)

\begin{tabular}{|c|c|c|c|c|c|c|c|c|}
\hline Site & Aquifer & $\begin{array}{l}\text { Salinity } \\
(\% o)\end{array}$ & $\begin{array}{l}\text { Pressure } \\
\text { (atm) }\end{array}$ & $X^{2}$ & $\begin{array}{l}\text { Probability } \\
(\%)\end{array}$ & $\begin{array}{l}\text { NGRT } \\
\left({ }^{\circ} \mathrm{C}\right)\end{array}$ & $\begin{array}{l}A \\
\left(\mathrm{~cm}^{3} \text { STP.kg }\right. \\
\end{array}$ & $\begin{array}{l}\Delta \mathrm{Ne} \\
(\%)\end{array}$ \\
\hline $08257 \times 0073$ & Olig. & 0.25 & 0.999 & 0.54 & 76.4 & $6.8 \pm 1.1$ & $2.8 \pm 0.6$ & 24.6 \\
\hline $08763 \times 0017$ & Olig. & 0.55 & 0.995 & 0.91 & 63.5 & $6.6 \pm 1.0$ & $2.0 \pm 0.6$ & 17.1 \\
\hline $08262 \times 0096 / \mathrm{F}$ & Olig. & 0.23 & 0.994 & 1.71 & 42.4 & $8.7 \pm 0.9$ & $2.4 \pm 0.1$ & 21.2 \\
\hline $07538 \times 0010$ & Olig. & 0.64 & 0.999 & 2.49 & 28.8 & $8.2 \pm 0.9$ & $1.9 \pm 0.6$ & 17.1 \\
\hline $8276 \times 0091$ & Olig. & 0.27 & 0.994 & 1.44 & 48.7 & $10.4 \pm 1.2$ & $3.4 \pm 0.6$ & 30.9 \\
\hline $08503 \times 0010$ & Olig. & $\begin{array}{l}0.30 \\
0.30\end{array}$ & $\begin{array}{l}0.997 \\
0.997\end{array}$ & $\begin{array}{l}2.13 \\
2.80\end{array}$ & $\begin{array}{l}34.4 \\
24.7\end{array}$ & $\begin{array}{l}11.9 \pm 1.1 \\
12.5 \pm 1.1\end{array}$ & $\begin{array}{l}3.6 \pm 0.8 \\
3.4 \pm 0.7\end{array}$ & $\begin{array}{l}33.2 \\
31.8\end{array}$ \\
\hline $08525 \times 0028$ & Olig. & $\begin{array}{l}0.45 \\
0.45\end{array}$ & $\begin{array}{l}0.991 \\
0.991\end{array}$ & $\begin{array}{l}0.24 \\
0.57\end{array}$ & $\begin{array}{l}88.9 \\
75.4\end{array}$ & $\begin{array}{l}6.5 \pm 1.1 \\
6.2 \pm 1.1\end{array}$ & $\begin{array}{l}3.2 \pm 0.8 \\
3.3 \pm 0.8\end{array}$ & $\begin{array}{l}28.3 \\
28.6\end{array}$ \\
\hline $08277 \times 0215$ & Eoc. & 0.30 & 0.999 & 0.65 & 72.4 & $8.4 \pm 1.1$ & $1.6 \pm 0.5$ & 13.8 \\
\hline $08277 \times 0152$ & Eoc. & 0.31 & 0.996 & 1.14 & 56.6 & $8.2 \pm 1.2$ & $1.6 \pm 0.6$ & 14.4 \\
\hline $08035 \times 0393$ & Eoc. & 0.76 & 0.998 & 1.41 & 49.5 & $5.9 \pm 1.0$ & $2.6 \pm 1.7$ & 22.3 \\
\hline $07792 \times 0006$ & Eoc. & 0.16 & 0.997 & 1.36 & 50.5 & $9.7 \pm 1.0$ & $5.2 \pm 1.0$ & 47.2 \\
\hline $08514 \times 0047$ & Camp. & 0.31 & 0.995 & 0.53 & 76.8 & $11.1 \pm 1.1$ & $3.4 \pm 1.5$ & 31.2 \\
\hline $08272 \times 0136$ & Camp. & $\begin{array}{l}0.30 \\
0.30\end{array}$ & $\begin{array}{l}0.998 \\
0.998\end{array}$ & $\begin{array}{l}2.26 \\
1.25\end{array}$ & $\begin{array}{l}32.3 \\
53.5\end{array}$ & $\begin{array}{l}4.7 \pm 1.0 \\
5.3 \pm 1.0\end{array}$ & $\begin{array}{l}2.8 \pm 1.2 \\
1.8 \pm 0.6\end{array}$ & $\begin{array}{l}23.8 \\
15.6\end{array}$ \\
\hline $08507 \times 0013$ & Aquit. & 0.26 & 0.995 & 0.88 & 64.5 & $9.9 \pm 1.2$ & $3.8 \pm 0.7$ & 34.1 \\
\hline
\end{tabular}

all the samples have $\delta^{13} \mathrm{C}_{\text {gas_eq }}$ enriched with respect to soil $\mathrm{CO}_{2}$ showing a closed system or a rapidly closing system with respect to soil $\mathrm{CO}_{2}$.

Low mineralized water $\left(\left[\mathrm{SO}_{4}{ }^{2-}\right]<60 \mathrm{mg} / \mathrm{L}\right)$ shows a rapid evolution of $\delta^{13} \mathrm{C}$ with mineralization, from -12.7 to $-3.4 \%$ o when sulfate concentration reaches $60 \mathrm{mg} / \mathrm{L}$. Such an evolution is a good argument for a closed system. For mineralized water $\left(\left[\mathrm{SO}_{4}{ }^{2-}\right]>60 \mathrm{mg} / \mathrm{L}\right)$, $\delta^{13} \mathrm{C}_{\text {gas eq }}$ is lower than $-9.6 \%$, showing that mineralization was also gained in a closed system after infiltration. It may be noted that water enriched in $\delta^{13} \mathrm{C}$ with respect to soil $\mathrm{CO}_{2}$, testifying to a closed system or a gradually closing system, was found in most calcareous aquifers. These samples also have low ${ }^{14} \mathrm{C}$ content.

\section{${ }^{14} \mathrm{C}$ models}

To assess the initial ${ }^{14} \mathrm{C}$ activity $A_{0}$, correction models are necessary (Fontes 1992) for water with a ${ }^{13} \mathrm{C}$ signature resulting from both limestone matrix and $\mathrm{CO}_{2}$ dissolution. The term $A_{0}$ refers to the initial ${ }^{14} \mathrm{C}$ content of the inorganic carbon dissolved in groundwater that occurs following recharge and water isolation from the $\mathrm{CO}_{2}$ reservoir of the unsaturated zone, while $A$ refers to the ${ }^{14} \mathrm{C}$ activity measured in water. The correction models are based on different mixing processes, i.e. pure chemical and isotopic mixing (Tamers 1975; Ingerson and Pearson 1964) and chemical mixing with isotopic exchange (Evans et al. 1979; Fontes and Garnier 1979; Mook 1980; Salem et al. 1980; Eichinger 1983). The
$\mathrm{C}$ end-member introduced in these calculations has the following isotopic contents:

${ }^{13} \mathrm{C}=-21 \%$ and $\mathrm{A}^{\mathrm{I} 4} \mathrm{C}=100 \%$ for biogenic $\mathrm{CO}_{2}$

${ }^{13} \mathrm{C}=0 \%$ and $\mathrm{A}^{14} \mathrm{C}=0$ pmc for solid carbonate

The calculated $A_{0}$ falls within a wide range of values (Tables 3 and 4). All the models taking into account a chemical and isotopic mixing with isotopic exchange in a dissolved $\mathrm{C}$-soil $\mathrm{CO}_{2}-\mathrm{CaCO}_{3}$ solid system give similar values. Higher values are provided by Tamers' model (Tamers 1975). These can be rejected for the samples for which the ${ }^{13} \mathrm{C}$ contents varies as a function of ${ }^{14} \mathrm{C}$ activity, suggesting carbon isotopic exchange between TDIC and the limestone matrix to have taken place through time, since such an exchange process is not taken into account in Tamers' approach (Tamers 1975).

Ages from Fontes-Garnier and Ingerson-Pearson models are close to each other, so the two models have been used to estimate the mean age value and the measurement uncertainty. For water with $\delta^{13} \mathrm{C}$ greater than $-6.2 \%$, the Eichinger model is also in good agreement with Fontes-Garnier and IngersonPearson models, so, for these waters, the three models have been used to calculate a mean age value.

The modeled ${ }^{14} \mathrm{C}$ ages were then converted into calendar ages using the Intcal13 calibration curve (Reimer et al. 2013) and the CalPal software (Weninger and Joris 2004). After calibration, the modeled ages are referred here to as age mod. BP (Before Present, i.e. 1950), to differentiate them from normal calibrated radiocarbon ages (age cal BP). 


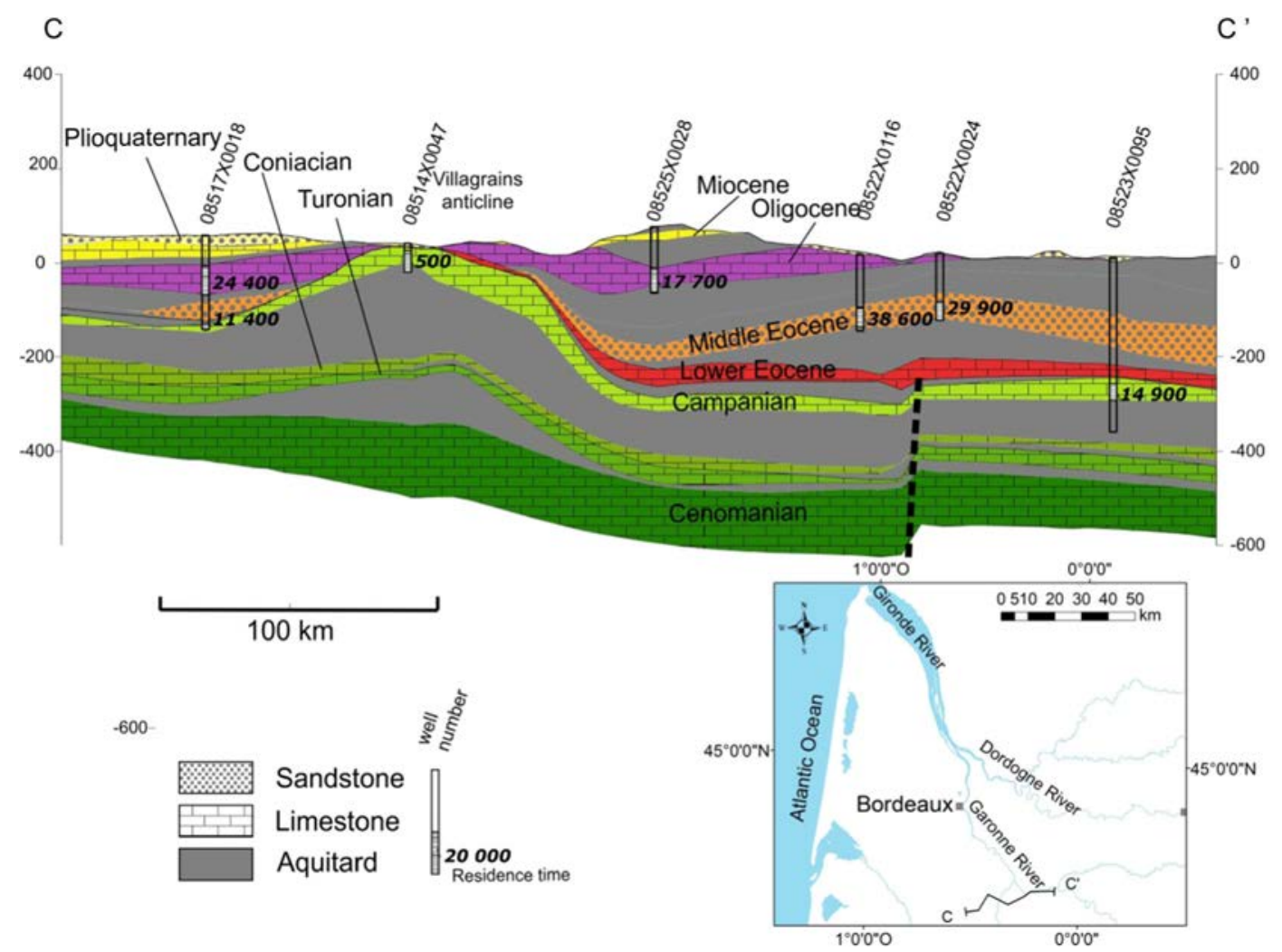

Fig. 5 Hydrogeological cross-section in the North Aquitaine multi-layered aquifer system and residence time distribution

\section{Noble gases and paleotemperatures estimation}

To estimate the reproducibility of noble gas measurements, four water samples were duplicated. For all noble gases, the reproducibility is generally better than $4 \%$, except for one He sample $(08503 \times 0010)$, probably due to a diffusive loss. The concentrations of dissolved noble gases are reported in Table 5.

Noble gas recharge temperatures (NGRT) were estimated by using the Noble90 program (Aeschbach-Hertig et al. 1999; Peeters et al. 2002). This program allows for assessing various models that differ on their estimation of excess air. The input data in these models are the salinity of groundwater, the atmospheric pressure at the recharge area, and the measured concentrations of dissolved noble gases with the exception of $\mathrm{He}$, which has a large non-atmospheric component. Salinities were estimated from the electrical conductivity at $20{ }^{\circ} \mathrm{C}\left(\kappa_{20}\right)$ according to the method proposed by Wüest et al. (1996) and the atmospheric pressure is related to the altitude of the recharge area (Aeschbach-Hertig et al. 1999). Electrical conductivities and altitudes of surface water were obtained from the BRGM (French Geological Survey) database (BRGM 2018). However, salinity and pressure have here a minor effect on NGRT results as their values are low in the studied area. The salinity of meteoritic groundwater is very low and estimated recharge heights range from 6 to $75 \mathrm{~m}$.

The closed system equilibration $(\mathrm{CE})$ model leans on the assumption that solubility equilibration is reached in a closed system of initially air-saturated water and a finite volume of air under hydrostatic pressure, corresponding to air bubbles trapped in the nonsaturated ground (Aeschbach-Hertig et al. 2000). This model, with the hypothesis of a pure air excess, best fits with the dataset. Table 6 presents the output parameters modeled by the Noble 90 software such as the NGRT, the amount of entrapped air $A_{\mathrm{e}}\left(\mathrm{cm}^{3}\right.$ STP of pure air per $\mathrm{kg}$ of water), and the excess air expressed by neon oversaturation percentage $(\Delta \mathrm{Ne})$. The mathematical method is based on the inverse theory: a combination of target parameters (NGRT and air excess for example) is calculated that would produce noble gas concentrations as close as possible to the measured concentrations. The minimum chi-squared value $\left(\chi^{2}\right)$ corresponding to the fit reliability between modeled and measured noble gas concentrations, and the probability, are reported in Table 6.

\section{Discussion}

\section{Residence time distribution}

A total of 120 values of residence time from groundwater of five aquifers were calculated from all the data collected in northern Aquitaine (Hosteins 1982; Chery 1993; Chery et al. 1994; Chery and Gadalia 2001; Bonnery et al. 1994; Platel et al. 1999; Schnebelen et al. 2002; Franceschi 2005; Saltel 2008; Malcuit 


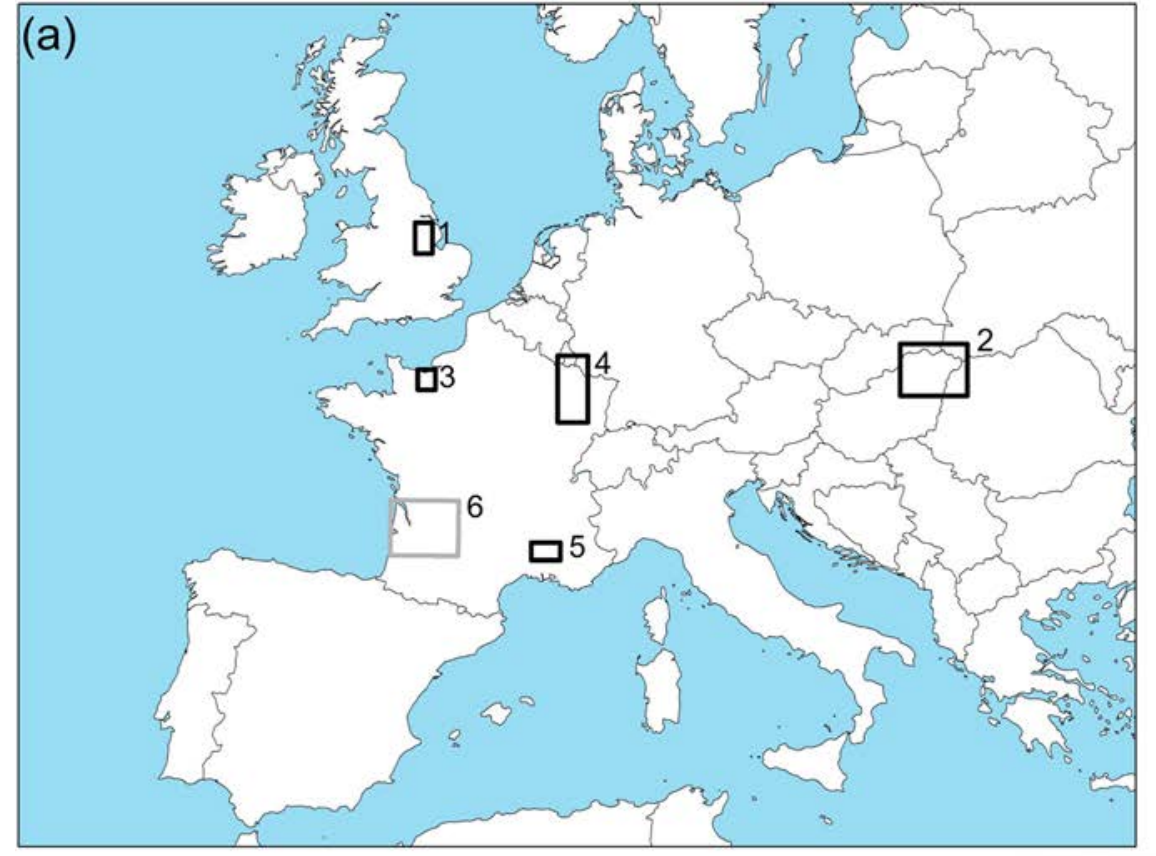

(c)

${ }^{14} \mathrm{C}$ age BP

$40000 \quad 3500030000 \quad 2500020000 \quad 1500010000 \quad 5000 \quad 0$

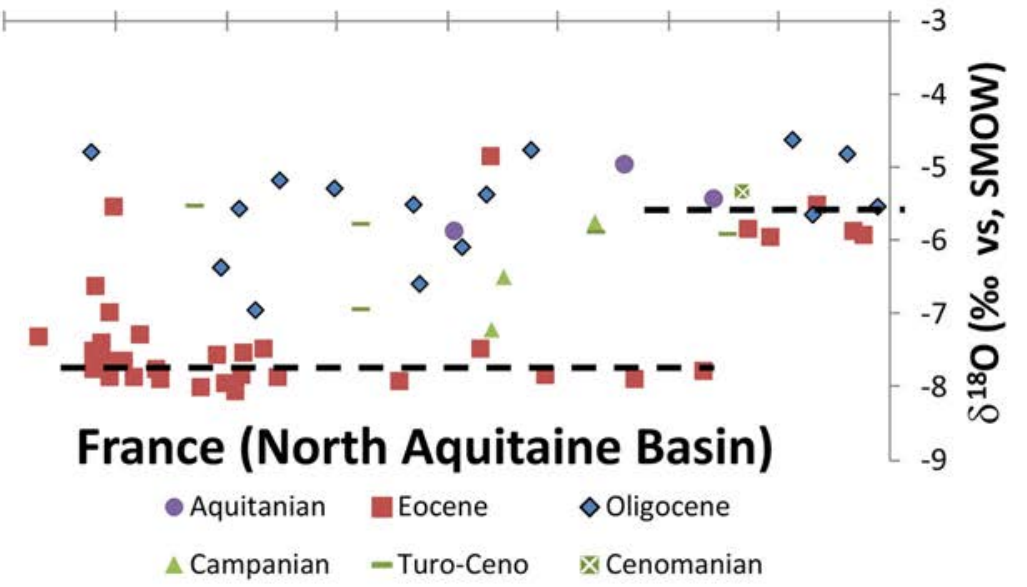

(b)

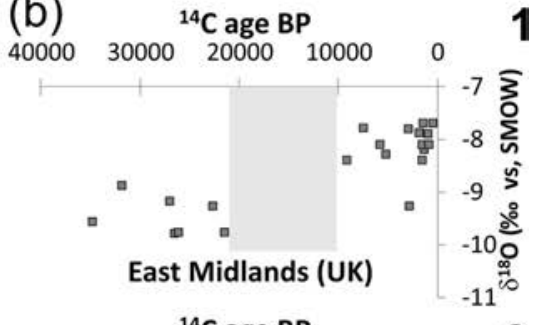

$40000 \quad 30000{ }^{14} \mathrm{C}_{20000}{ }_{10000} \quad 0 \quad \mathbf{2}$

$-8$

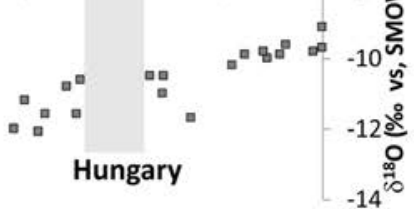

$\begin{array}{llllll}0000 & 30000 & 20000 & 10000 & 0 & 3\end{array}$

6

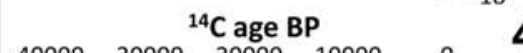

$\begin{array}{llll}40000 & 30000 \quad 20000 & 10000 \quad 0\end{array}$
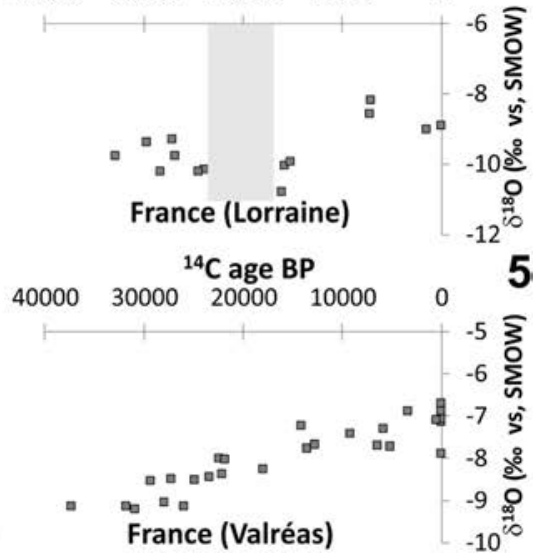

Fig. $6 \delta^{18} \mathrm{O}$ isotopic signatures of European groundwater during the last 40 ka. a Locations; b Data from previous studies: 1 in East Midlands, UK (Edmunds and Milne 2001); 2 in Hungary (Stute and Deák 1989); 3 in Normandy, France (Barbecot et al. 2000); 4 in Lorraine, France (Celle-
Jeanton et al. 2009); 5 in Valréas, France (Huneau et al. 2001) (1-4 show the recharge gap in grey and 5 shows continuous recharge); $\mathbf{c}$ Data from the study area (6) showing continuous recharge

compared with the sandy deposits of the middle Eocene aquifer. Besides, the geological structures such as the VillagrainsLandiras Anticline or major faults may also influence groundwater circulation leading locally to lower residences times. Overall, the distribution of residence times in the multi-layer aquifer system does not fit Toth's (1995) theoretical concept in which the residence time increases with depth.

In some areas, recent waters have been found among older waters. This is particularly the case near Bordeaux where several wells reach the middle Eocene aquifer. These anomalies may result from local contamination by recent water following faults or from damaged well casing leading to mixing of groundwater 


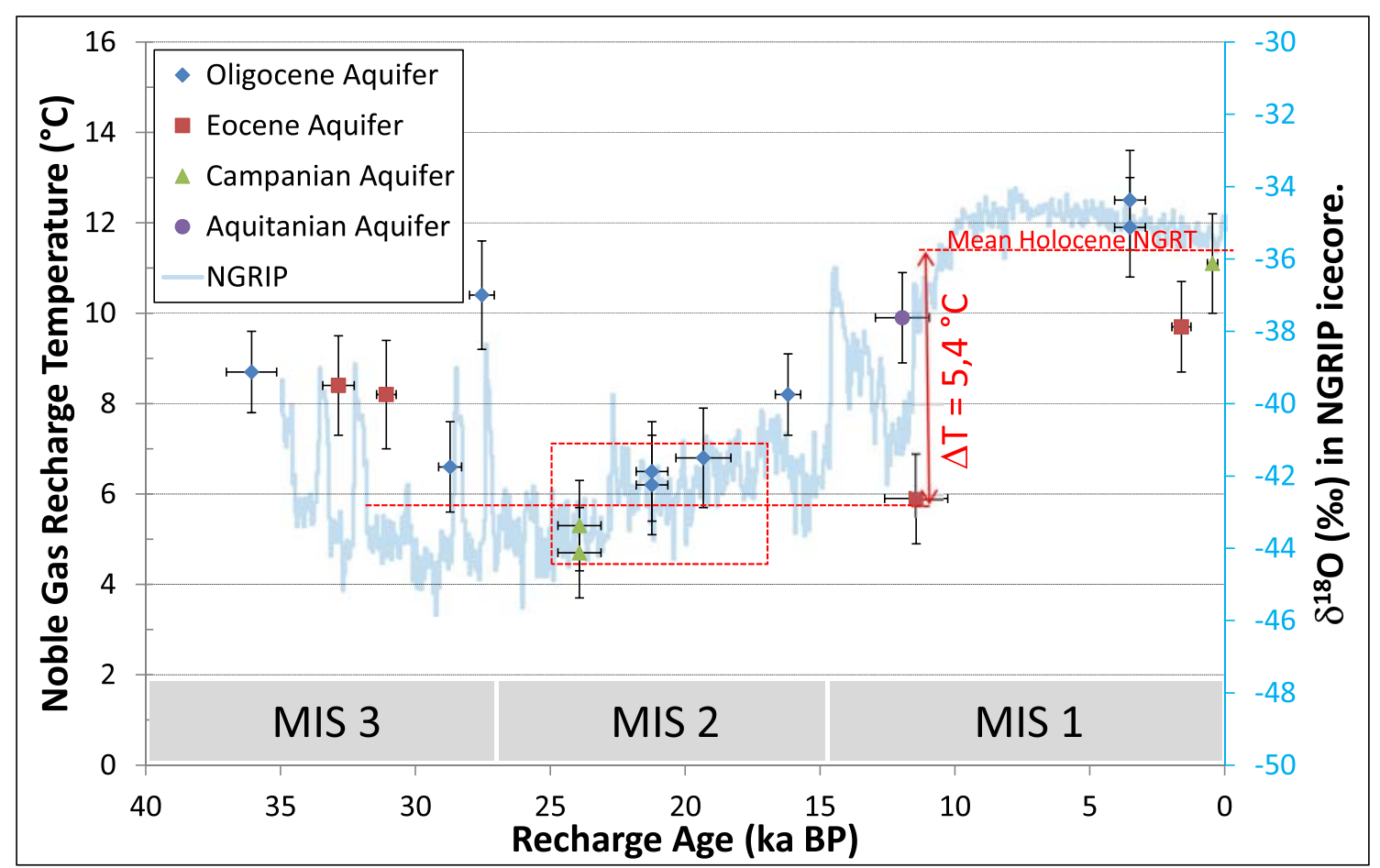

Fig. 7 Noble Gas Recharge Temperatures (NGRT) versus the recharge age of groundwater. NGRIP $\delta^{18} \mathrm{O}$ is from Rasmussen et al. (2014)

coming from various aquifers. The negative correlation between ${ }^{14} \mathrm{C}$ and $\delta^{13} \mathrm{C}$ in groundwater observed from the recharge areas to the drainage areas testifies to an important "dilution" of ${ }^{14} \mathrm{C}$ caused by the geochemical reactions with carbonates. Carbonate dissolution during infiltration also leads to higher $\delta^{13} \mathrm{C}$ values. As a consequence, the models that take into account chemical and isotopic mixing with isotopic exchange in a dissolved C-soil $\mathrm{CO}_{2}-\mathrm{CaCO}_{3}$ solid system (Ingerson and Pearson 1964; Fontes and Garnier 1979; Evans et al. 1979; Eichinger 1983) were considered to be the most appropriate to calculate $A_{0}$. The outputs of the different models are in good agreement. The differences obtained in residence time, together with the analytical error of ${ }^{14} \mathrm{C}$ and ${ }^{13} \mathrm{C}$ measurements were used to estimate the uncertainty associated with the residence time (Table 3). For the old data, an uncertainty was also calculated when the analytic error was available. Taking into account the uncertainty, the picture clearly emerges from the results that there is no gap in the age distribution, which means that the aquifers were recharged continuously (Fig. 6).

Studies on groundwater recharge across Europe give evidence for a recharge gap for many aquifers, which lasted some millennia to two tens of millennia, mostly between $\sim 30$ and 10 ka (Jiráková et al. 2011). These gaps are observed in Northern Europe and are thought to have been induced primarily by permafrost during the Last Glacial. The British-Irish and Scandinavian ice sheets also had a large influence on the investigated catchments in England, Denmark and Estonia. In contrast, the new data suggest that the aquifers in southern France may have been recharged continuously during the last $40 \mathrm{ka}$ (Fig. 6).
France is located in an intermediate area where precise estimation of paleopermafrost extent remains difficult and is still a matter of debate (Andrieux et al. 2016). According to isotopic data, an interruption of recharge is observed in the northern part of France (Normandy and Lorraine), whereas such a gap lacks in the southern part (Aquitaine, Provence). The available data set remains limited, however, making it impossible to bring to light any gap lasting one or a few millennia. The new data provided by this study, thanks to their large number (109), leave no doubt about the absence of recharge gap even during the coldest phases of the glacial. This strongly suggests that permafrost, if present, was not widespread enough to have had any significant impact on aquifer recharge.

In the light of this finding, the lack of speleothem growth shown in Villars Cave, which was interrupted between 31 and $15 \mathrm{ka}$ (Genty et al. 2010), is rather surprising. The factors involved may be (1) the existence of local permafrost due to favorable topographic conditions, although the persistence of frozen ground for a long time during the relatively milder parts of MIS 2 remains hardly plausible, (2) a deficit in atmospheric moisture supply on the Villars plateau that is away from any river-fed aquifer, as suggested both by GCMs reconstructions (Jost et al. 2005; Strandberg et al. 2011) and regional eolian sand extension (Sitzia et al. 2015), and (3) a combination of the two factors.

The new data set for northern Aquitaine (Fig. 6) also clearly shows a contrast between the $\delta^{18} \mathrm{O}$ of groundwater during the periods $\sim 40-35$ ka mod. BP (i.e. Marine Isotopic Stage (MIS) 3), $\sim 35-15$ ka mod. BP (late MIS 3 and MIS 2), and $\sim 15-0$ ka mod. BP (Lateglacial/Holocene, MIS 1). For the period 35-15 ka mod. 
$\mathrm{BP}$, groundwater is generally strongly depleted in ${ }^{18} \mathrm{O}$ when compared to both older water and Lateglacial/Holocene water. This is particularly true for groundwater sampled in the middle Eocene aquifer, which provides the best record of paleoclimate variations. Darling et al. (1997, 2004) already found that sandstone aquifers tend to be better archives than limestone aquifers because large scale porosity in the latter due to karstification leads to greater mixing of groundwaters. The $\delta^{18} \mathrm{O}$ of the Holocene samples is similar to that of present-day recharge as shown in Fig. 4 (Millot et al. 2010; Négrel and Petelet-Giraud 2011). Depletion in $\delta^{18} \mathrm{O}$ and $\delta^{2} \mathrm{H}$ is stronger for water with low ${ }^{14} \mathrm{C}$ activity (i.e. yielding an age older than $15 \mathrm{ka}$ mod. BP). This is assumed to reflect mostly temperature lowering during the glacial period.

Greater distance to the source of moisture due to westward retreat of the coastline during the LGM sea level lowstand (ca. $-120 \mathrm{~m}$ ) may also have been responsible to some extent for depletion due to isotopic fractionation between water vapor and liquid precipitation. Since the distance did not exceed $100 \mathrm{~km}$, this continental effect is assumed to have been insignificant. Similarly, the altitude effect (ca. $0.28 \% / 100 \mathrm{~m}$ for $\delta^{18} \mathrm{O}$, Poage and Chamberlain 2001) cannot explain the observed depletion range. It can be noticed that such a contrast between Holocene and late Pleistocene groundwater was also clearly observed in the UK (East Midlands) and in eastern France (Lorraine) as well, but is not as clearly identifiable in other European aquifers (Fig. 6).

\section{Paleotemperatures}

Associating noble gases recharge temperature (NGRT) with groundwater residence times makes it possible to reconstruct paleotemperatures since $40 \mathrm{ka}$ (Fig. 7). According to the data, the mean NGRT during the Holocene is $11.3 \pm 1.2{ }^{\circ} \mathrm{C}$. This value is in good agreement with the mean modern temperature of near surface aquifers in southwest France, which was estimated by Blavoux et al. (1993) to range between $11-13{ }^{\circ} \mathrm{C}$. Similarly, the study carried out by Huneau (2000) in southeast France gave a mean modern temperature of $12.7^{\circ} \mathrm{C}$.

Over the period 25-18 mod. ka BP (MIS 2), the NGRTs estimated in this work are quite homogeneous, and lead to a mean temperature equal to $5.9 \pm 0.9{ }^{\circ} \mathrm{C}$. Assuming that the present temperature of near-surface aquifers is $11.3^{\circ} \mathrm{C}$, the temperature decrease during the coldest period of MIS 2 relative to present is estimated at $5.4{ }^{\circ} \mathrm{C}$. This variation is coherent with previous NGRT studies made in Europe, i.e. $5-7^{\circ} \mathrm{C}$ in southwest France (Blavoux et al. 1993), $7{ }^{\circ} \mathrm{C}$ in southeast France (Huneau 2000), 3-9 ${ }^{\circ} \mathrm{C}$ in northeast France (Kloppmann et al. 1998), $4-7{ }^{\circ} \mathrm{C}$ in England (Bath et al. 1996), 5-7 ${ }^{\circ} \mathrm{C}$ in Germany (Rudolph et al. 1984; Bertleff et al. 1993), $6{ }^{\circ} \mathrm{C}$ in Austria (Andrews et al. 1985), $>5{ }^{\circ} \mathrm{C}$ in Switzerland (Beyerle et al. 1998) and $5-7{ }^{\circ} \mathrm{C}$ in the Czech Republic (Corcho Alvarado et al. 2011). Blaser et al. (2010) and Stute and Deák (1989) observed a more pronounced temperature drop respectively in Belgium $\left(>9.5{ }^{\circ} \mathrm{C}\right)$ and Hungary $\left(9^{\circ} \mathrm{C}\right)$.

For the MIS 3 samples (ages $>27$ mod. ka BP), the NGRT rises by approximately $2.6{ }^{\circ} \mathrm{C}$. According to the Greenland ice core isotopic record (Rasmussen et al. 2014), the latest part of MIS 3 is typified by rapid climate variation, with an alternation of short (a few hundred years long) warm interstadials and longer (in order of a millennium) cold stadials. Blavoux et al. (1993) in southwest France and Blaser et al. (2010) in Belgium also observed a similar NGRT evolution through the last $40 \mathrm{ka}$, showing a minimum during MIS 2 (in the Belgian record, just before and after a gap between 21 and $14 \mathrm{ka}$ ), followed by a rapid increase during the Lateglacial.

The mean reconstructed NGRT for the coldest period of MIS $2\left(5.9 \pm 0.9{ }^{\circ} \mathrm{C}\right)$ indicate that near-surface ground thermal conditions were significantly over $0{ }^{\circ} \mathrm{C}$ and, therefore, not adequate for long-term permafrost development in southwest France, as already suggested by the lack of recharge gap in the aquifers. The lowest NGRT value found in Leognan in southwest France $\left(5.0 \pm 0.4{ }^{\circ} \mathrm{C}\right)$ at $23.4 \pm 0.8 \mathrm{ka}$ mod. BP, also suggests that permafrost, even in favorable contexts (sporadic permafrost), was unlikely to occur during the coldest phases.

This finding is obviously in contradiction with the data provided by the analysis of periglacial features, which shows that ground ice bodies (i.e. composite wedges) were locally able to grow in northern Aquitaine (Andrieux et al. 2016). It cannot be excluded that smoothing of the temperature signal by the processes that took place within the aquifers, such as gas diffusion or water mixing, has filtered the high-frequency climate variability, so that the "cold phases" as recorded by noble gases are actually not representative of the coldest events, which may have lasted no more than a few hundred years. A similar "warm bias" seems also to emerge from the work of Blaser et al. (2010) in northern Belgium. The coldest NGRT found in this region is $0.7 \pm 0.3{ }^{\circ} \mathrm{C}$ at $\sim 24 \mathrm{ka}$, which is well above expected temperatures for widespread permafrost as reconstructed by Vandenberghe et al. (2014) and Andrieux et al. (2016). In current arctic environments, the mean annual ground temperature at the level of zero annual amplitude (a few meters below the ground surface) is typically lower than $-2{ }^{\circ} \mathrm{C}$ (usually between $-2{ }^{\circ} \mathrm{C}$ and $-5^{\circ} \mathrm{C}$ ) in the zone of widespread permafrost in northern Alaska and Canada (Smith et al. 2010), which translates into much colder mean annual air temperatures (MAATs) due to the thermal effect of vegetation and snow, and to the physical properties of the ground. Another plausible bias that may explain the discrepancies between reconstructed NGRTs and the temperature estimates derived from field proxies (periglacial features) is a decoupling between NGRTs and MAATs in cold environments. According to Singleton and Moran (2010) and Utting et al. (2012), NGRTs are strongly influenced by the temperature at the time of snow and ground ice melt, which may be significantly higher than the average yearly value in periglacial regions. In a permafrost environment from Canada, Utting et al. (2012) actually showed that NGRTs ranged 
between 0 and $5{ }^{\circ} \mathrm{C}$, whereas the MAAT was ca. $-8.9^{\circ} \mathrm{C}$. The studied aquifer was of limited extent, however, and such a large bias should not have affected the northern Aquitaine basin, which encompasses large recharge areas. Better evaluation of this bias in northern Aquitaine would need further investigations.

\section{Conclusion}

The new water samples retrieved from multi-layer aquifers in northern Aquitaine, southwest France, in addition to previously published data, provide the basis for the determination of residence times and the reconstruction of recharge temperatures through ${ }^{14} \mathrm{C}$ dating, analysis of water stable isotopes $\left(\delta^{18} \mathrm{O}\right.$ and $\left.\delta^{2} \mathrm{H}\right)$, and the measurement of dissolved noble gases $(\mathrm{He}, \mathrm{Ne}, \mathrm{Ar}, \mathrm{Kr}, \mathrm{Xe})$. In total 120 samples have been used to obtain modeled ages, 138 for $\delta^{18} \mathrm{O}$ and $\delta^{2} \mathrm{H}$ measurement, and 14 for noble gases.

The groundwater samples coming from the middle Eocene aquifer, which lies above the Upper Cretaceous multi-layer aquifer, yielded larger residence times. This anomaly is assumed to result from the complexity of the systems, namely the heterogeneity in lithology and permeability, and the geological structures. The data on residence time do not show any recharge gap of the aquifers for the last $40 \mathrm{ka}$. Late Pleistocene water and Holocene water clearly exhibit contrasted ${ }^{18} \mathrm{O}$ content, the former being significantly depleted when compared to present-day recharge.

During the coldest periods of MIS 2 (27 to -18 ka mod. BP), the mean near-surface ground temperature estimated from NGRT was $5.9 \pm 0.9^{\circ} \mathrm{C}$, implying that stable permafrost was unable to develop in the study region, which is consistent with the lack of recharge gap shown by the distribution of water ages. The lowest temperature recorded, close to $5.0^{\circ} \mathrm{C}$ at 23.4 \pm 0.8 ka mod. BP, strongly suggests that during the coldest phases of MIS 2, sporadic permafrost was also unlikely to occur even in favorable contexts. This finding does not agree with the data provided by the analysis of periglacial features such as thermal contraction cracks, which showed that ground ice bodies formed locally in northern Aquitaine. A plausible explanation lies in the smoothing of the paleoclimate signal in the aquifers due to diffusion and water mixing, making it impossible to detect short (i.e. a few hundred years) events that had nevertheless a significant impact on the landscape. Another possible bias lies in the fact that NGRTs in cold regions do not reflect annual means but rather the ground temperature during the thaw months. Further investigation on current NGRTs of large aquifers in a permafrost context could provide useful data to better estimate this bias. Holocene groundwaters indicate a mean NGRT of $11.3 \pm 1.1^{\circ} \mathrm{C}$, consistent with the mean modern temperature of near-surface aquifers in south France.
Acknowledgements The sampling campaign has been realized with the help of the Conseil départemental de la Gironde and SUEZ Environment who gave us access to their wells.

Funding information This work was financed by Adour-Garonne Water Agency and OASU (Observatoire Aquitain des Sciences de l'Univers) through the Special Program "Organics and Inorganics Contaminants".

\section{References}

Aeschbach-Hertig W, Solomon D (2013) Noble gas thermometry in groundwater hydrology. In: Burnard P (ed) The noble gases as geochemical tracers. Springer, Heidelberg, Germany, pp 81-122

Aeschbach-Hertig W, Peeters F, Beyerle U, Kipfer R (1999) Interpretation of dissolved atmospheric noble gases in natural waters. Water Resour Res 35(9):2779-2792

Aeschbach-Hertig W, Peeters F, Beyerle U, Kipfer R (2000) Palaeotemperature reconstruction from noble gases in ground water taking into account equilibration with entrapped air. Nature 405(6790): 1040-1044

Aggarwal P, Araguas-Araguas L, Gröning M, Kulkami K, Kuritas T, Newman B, Tanweer A (2009) Laser spectroscopic analysis of liquid water samples for stable hydrogen and oxygen isotopes. Training course 35, IAEA, Geneva, pp 1-35

Andrews JN, Wilson GB, Youngman MJ, Goldbrunner JE, Darling WG, Hooker PJ, Eichinger L, Rauert W, Stichler W (1985) A radiochemical, hydrochemical and dissolved gas study of groundwaters in the Molasse Basin of Upper Austria. Earth Planetary Sci Lett 73(2-4):317-332

Andrieux E, Bertran P, Saito K (2016) Spatial analysis of the French Pleistocene permafrost by a GIS database. Permafr Periglac Process 27:16-30

Antoine P, Goval E, Jamet G, Coutard S, Moine O, Hérisson D, Robert V (2014) Les séquences lossiques Pléistocène supérieur d'Havrincourt (Pas-de-Calais, France): stratigraphie, paléoenvironnements, géochronologie et occupations paléolithiques [The upper Pleistocene loessic sequences of Havrincourt (Pas-de-Calais, France): stratigraphy, paleoenvironments, geochronology and Palaeolithic settlement]. Quaternaire 25(4):321-368

Barbecot F, Marlin C, Gibert E, Dever L (2000) Hydrochemical and isotopic characterisation of the Bathonian and Bajocian coastal aquifer of the Caen area (northern France). Appl Geochem 15(6):791-805

Bath A, Edmunds W, Andrews J (1979) Palaeoclimatic trends deduced from the hydrochemistry of a Triassic sandstone aquifer, United Kingdom. International Atomic Energy Agency, Vienna

Bath AH, McCartney RA, Richards HG, Metcalfe R, Crawford MB (1996) Groundwater chemistry in the Sellafield area; a preliminary interpretation. Q J Eng Geol 29:39-57

Bertleff B, Ellwanger D, Szenkler C, Eichinger L, Trimborn P, Wolfendale N (1993) Interpretation of hydrochemical and hydroisotopical measurements on palaeogroundwaters in Oberschwaben, South German Alpine foreland, with focus on quaternary geology. International Atomic Energy Agency, Vienna

Bertran P, Andrieux E, Antoine P, Coutard S, Deschodt L, Gardère P, Hernandez M, Legentil C, Lenoble A, Liard M, Mercier N, Moine O, Sitzia L, Van Vliet-Lanoë B (2014) Distribution and chronology of Pleistocene permafrost features in France: database and first results. Boreas 43(3):699-711

Beyerle U (1999) Groundwater dynamics, paleoclimate and noble gases. Swiss Federal Institute of Technology, Zurich

Beyerle U, Purtschert R, Aeschbach-Hertig W, Imboden DM, Loosli HH, Wieler R, Kipfer R (1998) Climate and groundwater recharge during the last glaciation in an ice-covered region. Science 282:731-734 
Beyerle U, Aeschbach-Hertig W, Imboden DM, Baur H, Graf T, Kipfer R (2000) A mass spectrometric system for the analysis of noble gases and tritium from water samples. Environ Sci Technol 34:2042-2050

Blaser PC, Kipfer R, Loosli HH, Walraevens K, Van Camp M, Aeschbach-Hertig W (2010) A 40 ka record of temperature and permafrost conditions in northwestern Europe from noble gases in the Ledo-Paniselian aquifer (Belgium). J Quat Sci 25(6):1038-1044

Blavoux B, Dray M, Fehri A, Olive P, Groning M, Sonntag C, Hauquin JP, Pelissier G, Pouchan P (1993) Paleoclimatic and hydrodynamic approach to the Aquitaine basin deep aquifer (France) by means of environmental isotopes and noble gases. Proc. on applications of isotopes techniques in studying past and current environmental changes in the hydrosphere and the atmosphere. IAEA-SM-329/ 60, IAEA, Vienna, pp 293-305

Bonnery H, Peyrol L, Sourisseau B (1994) Étude du potentiel aquacole des nappes d'eau souterraines salées de la Pointe de Grave en Gironde [Study of the aquacultural potential of saline groundwaters near the "Pointe de Grave" area, Gironde Department]. BRGM/RR38074-FR, Technical report, BRGM, Orléans, France

BRGM (2018) Recherchez, visualisez et exploitez les données sur les eaux souterraines [Research, visualization and use of groundwater data]. www.ades.eaufrance.fr. Accessed December 2018

Celle-Jeanton H, Huneau F, Travi Y, Edmunds W (2009) Twenty years of groundwater evolution in the Triassic sandstone aquifer of Lorraine: impacts on baseline water quality. Appl Geochem 24(7):1198-1213

Chery L (1993) Interprétation des résultats des analyses isotopiques: etudes de la salinité verticale de l'Éocène moyen dans la zone Bordelaise (Gironde) [Result interpretation of the isotopic analyses: studies of the vertical salinity of the middle Eocene aquifer near Bordeaux area (Gironde department)]. BRGM/RR-37732-FR, Technical report, BRGM, Orléans, France

Chery L, Gadalia A (2001) Aide à la définition du périmètre de protection de la source de Fontbanne à Budos (33): interprétation des résultats d'analyses chimiques et isotopiques [Assistance to the definition of the protection perimeter of the spring of Fontbanne near Budos (Gironde Department): interpretation of the results of chemical analyses and isotopic]. EAU/GRI no. 2001/32, Technical report, BRGM, Orléans, France

Chery L, Dusseau P, Sourisseau B (1994) Diagnostic de l'accroissement de la salinité des nappes profondes de l'Éocène moyen en Gironde [Diagnosis of the increase in the salinity of the deep groundwaters of the middle Eocene in the Gironde Department]. BRGM/RR-37998FR, Technical report, BRGM, Orléans, France

Coope RG (2002) Changes in the thermal climate in northwestern Europe during marine isotope oxygen stage 3, estimated from fossil insect assemblages. Quat Res 57:401-408

Corcho Alvarado JA, Leuenberger M, Kipfer R, Paces T, Purtschert R (2011) Reconstruction of past climate conditions over Central Europe from groundwater data. Quat Sci Rev 30:3423-3429

Darling W (2004) Hydrological factors in the interpretation of stable isotopic proxy data present and past: a European perspective. Quat Sci Rev 23:743-770

Darling WG; Edmunds WM; Smedley PL (1997) Isotopic evidence for palaeowaters in the British Isles. Applied Geochemistry,12 (6). 813 829. https://doi.org/10.1016/S0883-2927(97)00038-3

Deák J, Stute M, Rudolph J, Sonntag C (1987) Determination of the flow regime of Quaternary and Pliocene layers in the Great Hungarian Plain (Hungary) by $\mathrm{D},{ }^{18} \mathrm{O},{ }^{14} \mathrm{C}$ and noble gas measurements. Isotope techniques in Water Resources Development. Proceedings IAEA Symposium, Vienna, IAEA Proceedings Series STI/PUB/ 757), IAEA, Vienna, pp 335-350

Deines P, Langmuir D, Harmon R (1974) Stable carbon isotope ratios and the existence of a gas phase in the evolution of carbonate groundwater. Geochim Cosmochim Acta 38:1147-1164
Dray M, Ferhi A, Jusserand C, Olive P (1997) Paleoclimatic indicators deduced from isotopic data in the main French deep aquifers. Isot Tech Study Environ Change (349/45):683-692

Edmunds WM, Milne CJ (eds) (2001) Palaeowaters in coastal Europe: evolution of groundwater since the late Pleistocene. Geol Soc Lond Spec Publ 189

Eichinger L (1983) A contribution to the interpretation of ${ }^{14} \mathrm{C}$ groundwater ages considering the example of a partially confined sandstone aquifer. Radiocarbon 25:347-356

Evans GV, Otlet RL, Downing RA, Monkhouse RA, Rae G (1979) Some problems in the interpretation of isotope measurements in United Kingdom aquifers. International Atomic Energy Agency, IAEA, Vienna

Eynaud F, Malaizé B, Zaragosi S, de Vernal A, Scourse J, Pujol C, Cortijo E, Grousset FE, Penaud A, Toucanne S, Turon JL, Auffret G (2012) New constraints on European glacial freshwater releases to the North Atlantic Ocean. Geophys Res Lett 39:L15601

Fletcher WJ; Goñi MFS, Allen JRM, Cheddadi R, Combourieu-Nebout N, Huntley B, Lawson I, Londeix L, Magri D, Margari V, Müller UC, Naughton F, Novenko E, Roucoux K, Tzedakis P (2010) Millennial-scale variability during the last glacial in vegetation records from Europe, Quaternary Science Reviews (29): 2839-2864

Fontes JC (1992) Chemical and isotopic constraints on ${ }^{14} \mathrm{C}$ dating of groundwater. In: Taylor R, Long A, Kra R (eds) Radiocarbon after four decades. Springer, New York, pp 242-261

Fontes JC, Garnier JM (1979) Determination of the initial ${ }^{14} \mathrm{C}$ activity of total dissolved carbon: a review of existing models and a new approach. Water Resour Res 15:399-413

Fontes JC, Stute M, Schlosser P, Broecker WS (1993) Aquifers as archives of paleoclimate. Eos Trans AGU 74(2):21-22

Ford DC (1993) Karst in cold environments. In: French HM, Slaymaker O (eds) Canada's cold environments. McGill-Queen's University Press, Montreal, pp 199-222

Franceschi M (2005) Analyses isotopiques - Forages de reconnaissances médocains [Isotope Analysis - exploratory borehole in the medoc area] Technical report, EGID

French HM (2007) The periglacial environment, 3rd edn. Wiley, Chichester, UK, $478 \mathrm{pp}$

Gély J, Sztrakos K (2000) L'évolution paléogéographique et géodynamique $\mathrm{du}$ Bassin aquitain au Paléogène: enregistrement et datation de la tectonique pyrénéenne [Paleogeographic and geodynamic evolution of the Aquitaine Basin during the Paleogene: recording and dating of Pyrenean tectonics]. Géol Fr 2:31-57

Genty D, Blamart D, Ouahdi R, Gilmour M, Baker A, Jouzel J, Van-Exter S (2003) Precise dating of Dansgaard-Oeschger climate oscillations in western Europe from stalagmite data. Nature 421(6925):833-837

Genty D, Blamart D, Ghaleb B, Plagnes V, Causse C, Bakalowicz M, Zouari K, Chkir N, Hellstrom J, Wainer K, Bourges F (2006) Timing and dynamics of the last deglaciation from European and north African $\delta 13 \mathrm{C}$ stalagmite profiles: comparison with Chinese and south hemisphere stalagmites. Quat Sci Rev 25:2118-2142

Genty D, Combourieu-Nebout N, Peyron O, Blamart D, Wainer K, Mansuri F, Ghaleb B, Isabello L, Dormoy I, Von Grafenstein U, Bonelli S, Landais A, Brauer A (2010) Isotopic characterization of rapid climatic events during OIS3 and OIS4 in Villars cave stalagmites (SW-France) and correlation with Atlantic and Mediterranean pollen records. Quat Sci Rev 29:2799-2820

Geyer S, Wolf M, Wassenaar LI, Fritz P, Buckau G, Kim JI (1993) Isotope investigations on fractions of dissolved organic carbon for ${ }^{14} \mathrm{C}$ groundwater dating. International Atomic Energy Agency, Vienna

Geyh MA, Backhaus G, Andres G, Rudolph J, Rath HK (1984) Isotope study on the Keuper Sandstone Aquifer with a leaky cover layer. In: Proceedings of IAEA-SM-270 Symposium, IAEA, Vienna, pp 499-513

Gombert P (1988) Étude des phénomènes de consolidation des aquifères et des désordres associés à l'exploitation des eaux souterraines: essai d'évaluation de l'influence de ces processus dans la région de Bordeaux [Study of the phenomena of consolidation of the aquifers 
and disorders associated with the exploitation of groundwaters: test of evaluation of the influence of these processes in the area of Bordeaux]. PhD Thesis Univ. Bordeaux 3, France, $319 \mathrm{pp}$

Guiot J, de Beaulieu J, Cheddadi R, David F, Ponel P, Reille M (1993) The climate in Western Europe during the Last Glacial/interglacial cycle derived from pollen and insect remains. Palaeogeogr Palaeoclimatol Palaeoecol 103:73-93

Heaton T, Vogel J (1981) “Excess air” in groundwater. J Hydrol 50:201216

Hosteins L (1982) Étude hydrogéologique du réservoir oligocène en Aquitaine occidentale: gestion et conservation de la ressource de cette nappe dans la région de Bordeaux [Hydrogeologic study of the Oligocene reservoir in Western Aquitaine: management and preservation of the groundwater resource in the area of Bordeaux]. $\mathrm{PhD}$ Thesis, Univ Bordeaux 1, France, $164 \mathrm{pp}$

Hughes PD, Gibbard PL (2015) A stratigraphical basis for the Last Glacial Maximum (LGM). Quat Int 383:174-185

Huneau F (2000) Fonctionnement hydrogéologique et archives $p$ laeoclimatiques d'un aquifère profond mediteranéen [Hydrogeological functioning and palaeogroundwaters of a deep Mediterranean aquifer]. PhD Thesis, Univ. Avignon, France, 180 pp

Huneau F, Blavoux B, Aeschbach-Hertig W, Kipfer R (2001) Paleogroundwaters of the Valréas Miocene aquifer (southeastern France) as archives of the LGM/Holocene transition in the western Mediterranean region. Proceedings of the International Conference on the Study of Environmental Changes Using Isotope Techniques (13):84-90

IAEA/WMO (2018) Global Network of Isotopes in Precipitation: the GNIP database. ttps://nucleus.iaea.org/wiser. Accessed 1 November 2018

Ingerson E, Pearson FJ (1964) Estimation of age and rate of motion of groundwater by the ${ }^{14} \mathrm{C}$-method. In: Recent researches in the fields of atmosphere, hydrosphere, and nuclear geochemistry, Maruzen, Tokyo, pp 263-283

Jiráková H, Huneau F, Celle-Jeanton H, Hrkal Z, Le Coustumer P (2011) Insights into palaeorecharge conditions for European deep aquifers. Hydrogeol J 19:1545-1562

Jost A, Lunt D, Kageyama M, Abe-Ouchi A, Peyron O, Valdes PJ, Ramstein G (2005) High-resolution simulations of the Last Glacial Maximum climate over Europe: a solution to discrepancies with continental palaeoclimatic reconstructions? Clim Dyn 24:557-590

Kageyama M, Laîné A, Abe-Ouchi A, Braconnot P, Cortijo E, Crucifix M, de Vernal A, Guiot J, Hewitt CD, Kitoh A, Kucera M, Marti O, Ohgaito R, Otto-Bliesner B, Peltier WR, Rosell-Melé A, Vettoretti G, Weber SL, Yu Y (2006) Last Glacial Maximum temperatures over the North Atlantic, Europe and western Siberia: a comparison between PMIP models, MARGO sea-surface temperatures and pollen-based reconstructions. Quat Sci Rev (25):2082-2102

Kloppmann W, Dever L, Edmunds W (1998) Residence time of chalk groundwaters in the Paris Basin and the north German Basin: a geochemical approach. Appl Geochem 13(5):593-606

Larroque F (2004) Gestion globale d'un système aquifère complexe: application à l'ensemble aquifère multicouche médocain [Global management of a complex aquifer system: application to the multi-layered aquifer system of the Médoc area]. PhD Thesis, Univ. Bordeaux 3, France, 253 pp

Larroque F, Treichel W, Dupuy A (2008) Use of unit response functions for management of regional multilayered aquifers: application to the North Aquitaine Tertiary System (France). Hydrogeol J 16(2):215233

Lavielle B, Matray JM, Thomas B, Dauzères A, Bensenouci F, Gilabert E (2012) Stages of evolution of a Toarcian compacted claystone around galleries excavated between 1 and 124 years ago by the study of noble gases dissolved in pore water at the Tournemire Underground Research Laboratory (France). Appl Geochem 27(7): 1403-1416
Le Gal La Salle C, Marlin C, Savoye S, Fontes J (1996) Geochemistry and ${ }^{14} \mathrm{C}$ dating of groundwaters from Jurassic aquifers of North Aquitaine Basin (France). Appl Geochem 11(3):433-445

Legigan P (1979) L'élaboration de la formation du Sable des Landes, dépôt résiduel de l'environnement sédimentaire PliocènePléistocène centre aquitain [The development of the "Sable des Landes" formation, residual deposit of the Pliocene-Pleistocene sedimentary environment Aquitaine basin]. PhD Thesis, Univ. Bordeaux 1, France, $253 \mathrm{pp}$

Malcuit E (2012) Origine de la minéralisation des eaux dans un aquifère multicouche profond: exemple de la "zone minéralisée de l'EntreDeux-Mers" (Bassin aquitain, France) [Origin of groundwaters' mineralization in a deep multi-layered aquifer: example of the "mineralized Entre-Deux-Mers area" (Aquitaine Basin, France)]. $\mathrm{PhD}$ Thesis, Univ. Bordeaux 3, France, $316 \mathrm{pp}$

Malcuit E, Atteia O, Larroque F, Franceschi M, Pryet A (2014) On the role of low-permeability beds in the acquisition of $\mathrm{F}$ and $\mathrm{SO}_{4}$ concentrations in a multi-layer aquifer, South-West France. J Contam Hydrol 169:97-49

Millot R, Petelet-Giraud E, Guerrot C, Négrel P (2010) Multi-isotopic composition $\left(\delta^{7} \mathrm{Li}-\delta^{11} \mathrm{~B}-\delta \mathrm{D}-\delta^{18} \mathrm{O}\right)$ of rainwaters in France: origin and spatio-temporal characterization. Appl Geochem 25(10):1510 1524

Mook W (1980) Handbook of environmental isotope geochemistry 1. Elsevier, Amsterdam

Négrel P, Petelet-Giraud E (2011) Isotopes in groundwater as indicators of climate changes. TrAC Trends Anal Chem 30(8):1279-1290

Osenbrück K, Lippmann J, Sonntag C (1998) Dating very old pore waters in impermeable rocks by noble gas isotopes. Geochim Cosmochim Acta 62(18):3041-3045

Parkhurst DL, Appelo CAJ (2013) Description of input and examples for PHREEQC version3: a computer program for speciation, batch-reaction, one-dimensional transport, and inverse geochemical calculations. US Geological Survey Techniques and Methods, book 6, chap. A43, US Geological Survey, Reston, VA, 497 pp

Pédron N, Platel JP, Bourgine B, Loiseau JB (2008) Gestion des eaux souterraines en Région Aquitaine: développements et maintenance du Modèle Nord-Aquitain de gestion des nappes - année 4, module 4 [Groundwater management in Aquitaine region: development and maintenance of the North-Aquitanian Model of groundwater management-year 4, module 4]. BRGM/RP-56614-FR, Technical report, BRGM, Orléans, France

Peeters F, Beyerle U, Aeschbach-Hertig W, Holocher J, Brennwalf MS, Kipfer R (2002) Improving noble gas based paleoclimate reconstruction and groundwater dating using ${ }^{20} \mathrm{Ne} /{ }^{22} \mathrm{Ne}$. Geochim Cosmochim Acta 67:587-600

Penna D, Stenni B, Sanda M, Wrede S, Bogaard TA, Gobbi A, Borga M, Fischer BMC, Bonazza M, Charova Z (2010) On the reproducibility and repeatability of laser absorption spectroscopy measurements for $\delta^{2} \mathrm{H}$ and $\delta^{18} \mathrm{O}$ isotopic analysis. Hydrol Earth Syst Sci 14(8):15511566

Platel JP, Mauroux B, Bonnery H, Sourisseau B, Seguin JJ, Chery L, Benhammoudas S, Dufour P (1999) Gestion des eaux souterraines en Aquitaine: relations entre l'estuaire de la Gironde et la nappe de l'Éocène [Groundwater management in Aquitaine region, year 3: relations between the estuary of the Gironde and the Eocene aquifer]. BRGM/RR-40729-FR, Technical report, BRGM, Orléans, France

Poage MA, Chamberlain CP (2001) Empirical relationships between elevation and the stable isotope composition of precipitation and surface waters: considerations for studies of paleoelevation change. Am J Sci 301:1-15. https://doi.org/10.2475/ajs.301.1.1

Ponel P (1995) Rissian, Eemian and Würmian Coleoptera assemblages from La Grande Pile (Vosges, France). Palaeogeogr Palaeoclimatol Palaeoecol 114:1-41 
Ramstein G, Kageyama M, Guiot J, Wu H, Hély C, Krinner G, Brewer S (2007) How cold was Europe at the Last Glacial Maximum? A synthesis of the progress achieved since the first PMIP model-data comparison. Clim Past 3:331-339

Rasmussen SO, Bigler M, Blockley SP, Blunier T, Buchardt SL, Clausen HB, Cvijanovic I, Dahl-Jensen D, Johnsen SJ, Fischer H, Gkinis V, Guillevic M, Hoek WZ, Lowe JJ, Pedro JB, Popp T, Seierstad IK, Steffensen JP, Svensson AM, Vallelonga P, Vinther BM, Walker MJC, Wheatley JJ, Winstrup M (2014) A stratigraphic framework for abrupt climatic changes during the last glacial period based on three synchronized Greenland ice-core records: refining and extending the INTIMATE event stratigraphy. Quat Sci Rev 106:14-28

Reimer PJ, Bard E, Bayliss A, Beck JW, Blackwell PG, Bronk Ramsey C, Buck CE, Cheng H, Edwards RL, Friedrich M, Grootes PM, Guilderson TP, Haflidason H, Hajdas I, Hatté C, Heaton TJ, Hoffmann DL, Hogg AG, Hughen KA, Kaiser KF, Kromer B, Manning SW, Niu M, Reimer RW, Richards DA, Scott EM, Southon JR, Staff RA, Turney CSM, van der Plicht J (2013) Intcal13 and Marine13 radiocarbon age calibration curves 0-50, 000 years cal BP. Radiocarbon 55(4):1869-1887

Roche DM, Dokken TM, Goosse TH, Renssen H, Weber SL (2007) Climate of the Last Glacial Maximum: sensitivity studies and model-data comparison with the LOVECLIM coupled model. Clim Past 3:205-224

Rudolph J, Rath H, Sonntag C (1984) Noble gases and stable isotopes in ${ }^{14} \mathrm{C}$-dated palaeowaters from Central Europe and the Sahara. In: Isotope hydrology 1983. IAEA-SM-270/17, International Atomic Energy Agency, Vienna, pp 467-477

Salem O, Visser J, Dray M, Gonfiantini R (1980) Groundwater flow patterns in the western Libyan Arab Jamahiriya evaluated from isotopic. International Atomic Energy Agency, Vienna

Saltel M (2008) Impact de structures géologiques sur l'alimentation de systèmes aquifères profonds: fonctionnement hydrogéologique des antiformes du sud de Bordeaux [Impact of geological structures on the recharge of deep aquifer systems: hydrogeological behaviour of antiforms in the south of Bordeaux]. PhD Thesis, Univ. Bordeaux 3 , France, $268 \mathrm{pp}$

Schnebelen N, Platel JP, Petelet-Giraud E, Dubreuilh J, Benhammouda S, Dufour P (2002) Gestion des eaux souterraines en Aquitaine: année 5-relations entre l'estuaire de la Gironde et la nappe de l'Éocène [Groundwater management in Aquitaine region: year 5-relations between the estuary of the Gironde and the Eocene aquifer]. BRGM/RP-51177-FR, Technical report, BRGM, Orléans, France

Schoeller H (1971) Paléohydrogéologie de la partie septentrionale du bassin d'Aquitaine. Etablissement d'une série de cycles hydrogéologiques, avec stages d'essorage et d'infiltration pendant les ères secondaire et tertiaire [Paleohydrogeology of the northern part the Aquitaine basin: establishment of set of hydrological cycles, with various stages of drying and infiltration during the eras secondary and tertiary]. Bull Soc Geol Fr 1:47-49

Seltzer AM, Stude M, Morgenstern U, Stewart MK, Schaefer JM (2015) Mean annual temperature in New Zealand during the Last Glacial Maximum derived from dissolved noble gases in groundwater. Earth Planet Sci Lett 431:206-216

Singleton M, Moran J (2010) Dissolved noble gas and isotopic tracers reveal vulnerability of groundwater in a small, high-elevation catchment to predicted climate changes. Water Resour Res 46:W00F06
Sitzia L, Bertran P, Bahain JJ, Bateman M, Hernandez M, Garon H, de Lafontaine G, Mercier N, Leroyer C, Queffelec A, Voinchet P (2015) The Quaternary coversands of Southwest France. Quat Sci Rev 124:84-105

Smith SL, Romanovsky VE, Lewkowicz AG, Burn CR, Allard M, Clow GD, Yoshikawa K, Throop J (2010) Thermal state of permafrost in North America: a contribution to the International Polar Year. Permafr Periglac Process 21:117-135

Strandberg G, Brandefelt J, Kjellström EK, Smith B (2011) Highresolution regional simulation of Last Glacial Maximum climate in Europe. Tellus 66A:107-125

Stute M, Deák J (1989) Environmental isotope study $\left({ }^{14} \mathrm{C},{ }^{13} \mathrm{C},{ }^{18} \mathrm{O}, \mathrm{D}\right.$, noble gases) on deep groundwater circulation systems in Hungary with reference to paleoclimate. Radiocarbon 31:902-918

Stute M, Schlosser P (1993) Principles and applications of the noble gas paleothermometer. Climate Change Continental Isotopic Records 8: $89-100$

Tamers M (1975) The validity of radiocarbon dates on groundwater. Geophys Surv 2:217-239

Texier J (1996) Présence d'un réseau de grands polygones au Sud de l'estuaire de la Gironde (France): interprétation et implications paléoclimatiques [Presence of large non-sorted polygons located on the south side of the Gironde estuary (France): interpretation and paleoclimatic implications]. Geog Phys Quat 50:103-108

Tóth J (1995) Hydraulic continuity in large sedimentary basins. Hydrogeol J 3(4):4-16

Utting N, Clark I, Lauriol B, Wieser M, Aeschbach-Hertig B (2012) Origin and flow dynamics of perennial groundwater in continuous permafrost terrain using isotopes and noble gases: case study of the Fishing Branch River, northern Yukon, Canada. Permafr Periglac Process 23:91-106

Vandenberghe J, French HM, Gorbunov A, Marchenko S, Velichko AA, Jin H, Cui Z, Zhang T, Wan X (2014) The Last Permafrost Maximum (LPM) map of the Northern Hemisphere: permafrost extent and mean annual air temperatures, $25-17 \mathrm{ka}$ BP, Boreas (43): 652-666

Van Vliet-Lanoë B (1989) Dynamics and extent of the Weichselian permafrost in western Europe (substage 5e to stage 1). Quat Int 3-4: 109-113

Van Vliet-Lanoë B (1996) Relations entre la contraction thermique des sols en Europe du Nord-Ouest et la dynamique de l'inlandsis weichselien [Soil thermal contraction in NW Europe related to the dynamics of Weichselian Ice Sheet]. CR Acad Sci Paris 322(série IIa):461-468

Vidstrand P (2003) Surface and subsurface conditions in permafrost areas: a literature review. Swedish Nuclear Fuel and Waste Management Co, Stockholm, 70 pp

Weninger B, Joris O (2004) Glacial radiocarbon calibration. The CalPal program radiocarbon and archaeology. In: Higham T, Ramsey CB, Owen C (eds) Radiocarbon and archaeology. Oxford University School of Archaeology, Oxford, pp 9-15

Wüest A, Piepke G, Halfman J (1996) Combined effects of dissolved solids and temperature on the dentsity stratification of Lake Malawi. In: The limnology, climatology and paleoclimatology of the eastern African lakes. CRC Press, Boca Raton, FL, pp 183-202 